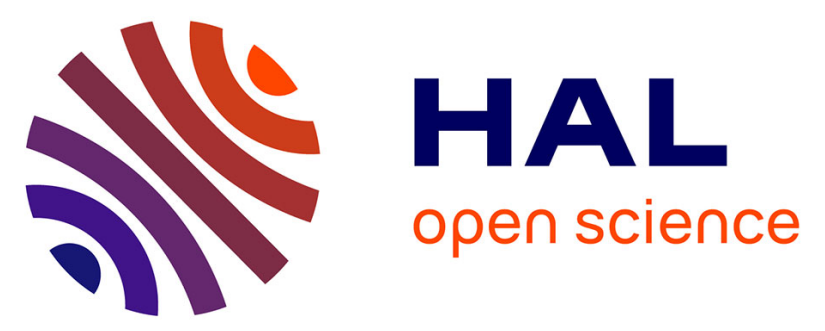

\title{
Gravity inversion, AMS and geochronological investigations of syntectonic granitic plutons in the southern part of the Variscan French Massif Central
}

Aurore Joly, Michel Faure, Guillaume Martelet, Yan Chen

\section{To cite this version:}

Aurore Joly, Michel Faure, Guillaume Martelet, Yan Chen. Gravity inversion, AMS and geochronological investigations of syntectonic granitic plutons in the southern part of the Variscan French Massif Central. Journal of Structural Geology, 2009, 31 (4), pp.421-443. 10.1016/j.jsg.2009.01.004 • insu00352868

\section{HAL Id: insu-00352868}

https://hal-insu.archives-ouvertes.fr/insu-00352868

Submitted on 14 Jan 2009

HAL is a multi-disciplinary open access archive for the deposit and dissemination of scientific research documents, whether they are published or not. The documents may come from teaching and research institutions in France or abroad, or from public or private research centers.
L'archive ouverte pluridisciplinaire HAL, est destinée au dépôt et à la diffusion de documents scientifiques de niveau recherche, publiés ou non, émanant des établissements d'enseignement et de recherche français ou étrangers, des laboratoires publics ou privés. 


\title{
Gravity inversion, AMS and geochronological investigations of syntectonic granitic plutons in the southern part of the Variscan French Massif Central
}

Joly Aurore ${ }^{1, *}$, Faure Michel$^{2}$, Martelet Guillaume ${ }^{3}$ and Chen Yan ${ }^{2}$

\author{
${ }^{1}$ Centre for Exploration Targeting, M006 35 Stirling Highway CRAWLEY WA 6009, \\ ${ }^{2}$ Institut des Sciences de la Terre d'Orléans, UMR CNRS 6113, Université d'Orléans, 1A \\ rue de la Férollerie, F45071, ORLEANS Cedex 2, France \\ ${ }^{3}$ Bureau de Recherches Géologiques et Minières, 3 avenue Claude Guillemin, BP 6009, \\ F45060, ORLEANS Cedex 2, France \\ *Corresponding author: aurore.joly@gmail.com (fax number: +61 86488 1178)
}

\begin{abstract}
Magnetic fabric analyses, gravity inversion associated with chemical U-Th- $\mathrm{Pb}$ dating and structural observations are carried out to elucidate relationships between faulting and magmatic processes. This multidisciplinary study has been undertaken on Late Carboniferous plutons, situated in the southern part of the Variscan French Massif Central (FMC). The Glénat, Omps and Boisset plutons crop out on both sides of the crustal-scale Sillon Houiller Fault (SHF). The Anisotropy of Magnetic Susceptibility (AMS) measurements and structural observations show that (i) the plutons acquired their final structure during the magma crystallization and record a NW-SE maximum stretching trend; (ii) in the Boisset pluton, post magmatic fabrics predominate with a NNW-SSE trending lineation. The structural pattern deduced from the AMS study is thus consistent with the NW-SE late orogenic extensional tectonic regime that has been
\end{abstract}


documented in other parts of the FMC during Late Carboniferous. The 3D geological modelling refined by $3 \mathrm{D}$ gravity inversion does not show any evidence of rooting of the granites along the SHF. Therefore, despite the apparent cartographic relationship between the SHF and the three plutons, our study does not support a genetic link between fault and plutons. It also questions the existence of the SHF in this part of the Massif Central at the time of pluton emplacement, and emphasises the dominant role of the regional tectonic framework rather than local faulting as a factor controlling pluton emplacement.

Keywords: granite fabrics, monazite chemical U-Th-Pb dating, Anisotropy of Magnetic Susceptibility (AMS), gravity investigations and inversion, 3D modelling, Variscan Belt, Sillon Houiller Fault.

\section{Introduction}

Since last two decades, the scientific community places increasing interest in the relationships between magmatic processes, pluton architecture and emplacement, as well as the role played by regional or local structures (e.g. Hutton 1982, 1988; Castro, 1986; Clemens and Mawer 1992; D’Lemos et al 1992; McCaffrey 1992; Tikoff and Teyssier 1992; Neves and Vauchez 1995, Tikoff and Saint Blanquat 1997; Crawford et al. 1999; McNulty et al. 2000). The collapse of mountain belts is often accommodated by ductile extensional tectonics, crustal melting and syntectonic magma emplacement (e. g. Malavieille 1993; Faure 1995; Vanderhaege and Teyssier 2001). However, the mechanisms of pluton emplacement and to what extent their emplacement can be related 
to nearby structures, such as faults or folds, is still a matter of debate (e.g. Paterson and Schmidt 1999).

Monazite $\mathrm{U}-\mathrm{Th}-\mathrm{Pb}$ chemical dating of granitic massifs is now increasingly used to address geochronological questions as it provides accurate and fast age determination that allow to constrain tectonic belt evolution and pluton emplacement (Cocherie and Albarede 2001; Cocherie et al. 2005; Be Mezème et al. 2006a, 2006b). Granitic bodies often record tectonic regimes developed during a short time interval. Granitic plutons can be used as kinematic markers allowing a detailed reconstruction of the late stages of the tectonic evolution of orogenic belts and also understand the mechanism of pluton emplacement (Gleizes et al. 1997; Benn et al. 2001).This is the case for the late stage of the evolution of the Variscan French Massif Central (FMC, Figure 1, e. g. Faure and Pons 1992; Faure 1995; Talbot et al. 2004, 2005a, 2005b; Gébelin et al. 2004).

The anisotropy of magnetic susceptibility (AMS) is a powerful tool to investigate the internal structures of plutons where the macroscopic preferred mineral orientation is poorly expressed or absent (e.g. Bouchez 1997). In particular, the lineation is often difficult to observe in the field because, unless they are significantly deformed, granitoids do not develop planar and linear fabrics that can be easily observed. The advantage of using magnetic techniques in fabric studies of plutons lies in the fact that precise, reproducible and efficient foliation and lineation measurements can be obtained for any outcrops in a pluton (Hrouda 1982; Bouchez 1997, 2000). The analysis of petrographic textures and fabrics developed in a pluton and its wall rocks allow us to present a model delineating the rheological evolution of the magma during the pluton emplacement history. 
In addition, the knowledge of the 3D shape of a pluton brings important information on the emplacement process, for example, by locating the possible feeder zones (Vigneresse 1990; Aranguren et al. 1996; Améglio et al. 1997; Joly et al. 2008) and by defining the relationships between the host rocks and the granitic pluton. Several studies illustrate the usefulness of combining gravity and structural data when investigating the emplacement mode and structural evolution of a granitic pluton (e.g. Améglio et al. 1997; Vigneresse and Bouchez 1997; Talbot et al. 2004). In order to obtain a consistent model, the 3D geological model is directly computed from the available structural data (field observations and AMS results) and constrained by geophysical data (Martelet et al. 2004; Joly et al. 2008). Namely, the geological boundaries at depth are assessed by inversion of gravity data (Guillen et al., 2008), and their uncertainties are quantified in a statistical way (Tarantola and Valette 1982; Li and Oldenburg 1998). With respect to forward modelling, this inversion procedure provides a fast and statistically robust estimate of probable 3D geometries and density contrasts.

This paper presents the results of a combined structural, geochronological, AMS and gravity investigation of Glénat, Omps and Boisset plutons in the southern part of the Variscan French Massif Central (Figure 1). The architecture, kinematics, and timing of these Carboniferous plutons are discussed in the structural framework of the late orogenic evolution of the Variscan chain of the FMC. The relationships between the emplacement of these plutons and the nearby Sillon Houiller Fault (SHF) are considered and compared with previous results obtained in the northern part of the SHF (Joly et al. 2007, 2008).

\section{Geological setting}




\subsection{Regional tectonic framework}

The Variscan Belt was built up in the Paleozoic time as the consequence of the collision between Gondwana and Laurussia continents in the South and North, respectively (e.g. Matte 1986; Paris and Robardet 1990; Franke 2000). The French Massif Central (Figure 1b) is one of the largest sectors of the Variscan belt of Western Europe. It is now well established that several ductile thrusting events in the FMC took place in the Devonian and Early Carboniferous (e.g. Ledru et al. 1989; Faure et al. 2005 and enclosed references). In the late Visean time (ca $335 \mathrm{Ma}$ ), the onset of the syn-orogenic extension occurred (Van den Driessche and Brun 1989) and was coeval with magmatism in the northern part of the FMC. In the southern Massif Central, or Cévennes area (Figure 1b), the top to south syn-metamorphic thrusting occurred at ca $340 \mathrm{Ma}$ (e.g. Najoui et al. 2000; Faure et al. 2001 and enclosed references). During the Late Carboniferous times (320-290 Ma), the entire belt experienced extensional tectonics (Faure 1995). It is worth noting that the orogenic collapse is diachronous at the scale of the FMC, beginning earlier in the north than in the south of the FMC. Moreover, extensional tectonics can be divided into late and post-orogenic events (Faure and Becq-Giraudon 1993; Faure 1995). The former event is accommodated by an orogen-parallel NW-SE maximum stretching and coeval with the emplacement of numerous leucogranitic to porphyritic monzogranitic plutons (Faure 1995). The later event is characterized by i) a N-S to NE-SW trending maximum stretching direction, ii) the opening of small but numerous coal basins, and iii) the emplacement of the ca. 300 Ma Velay migmatitic dome (Malavieille et al. 1990; Burg et al. 1994; Ledru et al. 2001). 
The NNE-SSW trending Sillon Houiller fault (SHF) is a major structure of the FMC. Its Late Carboniferous (Stephanian) left-lateral brittle motion is well documented (Letourneur 1953; Grolier and Letourneur 1968; Bonijoly and Castaing 1987; Blès et al. 1989). It has been argued that the SHF was a transfer fault that accommodated the extensional tectonics of the FMC (Burg et al. 1990). However, this hypothesis must be carefully considered since it does not distinguish the different kinematics between the late and post extensional phases. Indeed, when dealing with the post-orogenic event, this interpretation is in agreement with available data (Bonijoly and Castaing 1987; Blès et al. 1989; Burg et al. 1990; Faure 1995) since it may account for the development of transtensional pull-apart coal basins. However, when dealing with the syn-orogenic event, the N-S trend of the SHF is not in agreement with the NW-SE ductile stretching that developed at that time, as observed in most parts of the FMC (Faure, 1995).

Therefore, the questions arise of the existence, kinematics and rheological behaviour (i.e. brittle or ductile) of the SHF in Namurian-Westphalian times. An element of answer has been provided in the northernmost part of the SHF. There, it has been shown that the ca. 320 Ma Montmarault pluton was rooted on its SE border along the SHF and spread to the NW (Joly et al. 2007, 2008). Thus if the fault already existed in Namurian times, it should have behaved as a dilatant zone representing the feeder zone of the Montmarault pluton. Along the Southern part of the SHF, several plutons crop out along the brittle SHF, but little is know about the relations between the SHF and the plutons at the time of their emplacement.

\subsection{The southern part of the SHF}


The structural map of the southern part of the SHF displays several geological units (Figure 1a). The "Châtaigneraie" and "Millevaches" micaschist series that crop out in the eastern and western sides of the SHF belong to the Para-Autochthonous Unit (Ledru et al. 1989); they constitute the plutons host-rock. In the Châtaigneraie micaschists, the foliation trends NW-SE in the southern part, around the Marcolès and Veinazès plutons, and turns toward to the north near the Omps pluton, with NE to eastward dips. On the northeastern part of the study area, the Lower Gneiss Unit (LGU) formed by medium pressure and temperature metagraywackes and metapelites, overthrusts to the southwest the Para-Autochthonous Unit.

The Millevaches micaschists, pinched between the SHF and Argentat fault, exhibit various attitudes. They are intruded by leucogranites (Vivier and Lasseyre 1973; Gébelin et al. 2004). To the southwest, the Millevaches series is overthrust by high grade allochthonous gneiss units. In Figure1a, the Upper Gneiss and Lower Gneiss Units (Ledru et al. 1989) are not distinguished. Lastly, the sandstone and pelite Thiviers-Payzac Unit forms the uppermost unit of the stack of nappes.

The Glénat, Omps and Boisset plutons (Figures 1 and 2; Vivier 1970; Feybesse 1981) intrude the metamorphic series. In the geological map (Figure 1a), the three plutons appear in close vicinity; however, it is worth noting that this present situation results from the Stephanian left lateral movement of the SHF. In fact, at the time of its emplacement, the Glénat pluton was located about $80 \mathrm{~km}$ north of the Omps and Boisset ones. Along this segment of the SHF, coal-bearing pull-apart basins are rare. At the northwestern end of the Omps pluton, Late Carboniferous (Stephanian) sandstone and mudstone beds are 
turned to vertical. Subhorizontal slickenlines associated to a left-lateral brittle shearing are common (Gélard et al. 1986; Bonijoly and Castaing 1987).

To the east of the study area, the Marcolès and Veinazès porphyritic plutons (Figure 1a) have been dated by ${ }^{40} \mathrm{Ar} /{ }^{39} \mathrm{Ar}$ method on biotites around $315 \mathrm{Ma}$ (Monié et al. 1999). AMS measurements have been made to determine the pluton structure (Olivier and Améglio 2002). The magnetic foliation of the Marcolès massif and the western part of Veinazès pluton is mainly WNW-ESE to NW-SE trending with a medium to steep northward dip. Most of the magnetic lineations in both plutons trend NW-SE to E-W, with a moderate $\left(20^{\circ}\right.$ to $\left.45^{\circ}\right)$ southeastward plunge (Olivier and Améglio 2002).

\section{Structure of the Glénat, Omps and Boisset plutons}

\subsection{Glénat, Omps and Boisset plutons and contact aureole}

The Glénat pluton is composed of two facies, namely a blue grey porphyritic one and a medium grained with globular quartz grains one, to the west and east, respectively. Situated to the east of the SHF, the Omps pluton is composed of a grey homogeneous porphyritic rock with a $500 \mathrm{~m}$ to $1000 \mathrm{~m}$ wide cataclazed zone developed on (Figure 2a, Vivier; 1970). The $25 \mathrm{~km}$-long Boisset pluton develops in the south of the Omps body (Figure 1a). This middle grained rock is mineralogically and chemically similar to the Omps monzonitic granite (Vivier 1970), but its macroscopic fabric is significantly different since the rock exhibits a conspicuous foliation (Figure 2b).

These three plutons are surrounded by a metamorphic aureole of ca $1 \mathrm{~km}$ in width developed in the country rocks (Figure 1a). Between the Boisset and Marcolès plutons, the country rocks throughout more than $2 \mathrm{~km}$ are transformed into hornfels. In the 
vicinity of the plutons, the regional foliation is deformed by a NW-SE crenulation or by post folial folds with axes parallel to this crenulation. Immediately at the pluton contact, the host rock consists sometimes of massive black hornfels, but more generally, the regional foliation is overprinted by biotite, muscovite, andalusite, garnet or cordierite porphyroblasts. The contact metamorphic minerals such as micas or andalusite, frequently oriented along a NW-SE or NNW-SSE trend, define a mineral lineation. In sections perpendicular to the foliation and parallel to the mineral lineation, the metamorphic minerals are boudinaged, and shear criteria are well developed. For instance, garnet porphyroblasts fringed by quartz or chlorite asymmetric pressure shadows (Figure 3a), sigmoidal shapes of muscovite or oxide minerals (Figure 3b), feldspar surrounded by asymmetric quartz pressure shadows (Figure 3e), shear bands (Figure 3c), polycrystalline quartz aggregates with an oblique shape fabric of the recrystallized neograins (Figure 3d), commonly indicate a top-to-the SE sense of shear. The primary minerals are also deformed, for instance staurolite grains, formed during the early regional metamorphism coeval with the regional compressive event (Faure et al. 2005; Duguet et al. 2007), are boudinaged (Figure 3f) and the voids are filled by quartz or chlorite aggregates.

As a whole, in the study area, the NW-SE stretching is coeval with the plutons emplacement. The kinematic indicators show a normal motion, with the host rock being down-faulted with respect to the granite. On the western margin of the Glénat pluton, the sense of shear is top-to-the west or NW, and in the eastern margin of the Omps and Boisset plutons, the sense of shear is top-to-the-east or SE. 


\subsection{Macroscopic structures within the plutons}

Numerous horizontal slickenlines developed on N-S trending fault planes develop in the plutons in the vicinity of the SHF. These brittle structures are the only ones that can be related to deformation along the SHF. The statistical analyses of jointing, enclaves, schlieren and K-feldspar megacrysts (KFM) preferred orientation have been carried out in the Glénat, Omps and Boisset plutons (Feybesse 1981). According to this study, in the Glénat pluton, the KFM fabric is rather scattered, but horizontal or shallow dip planar predominates.

Within the Omps pluton, the KFM planar preferred orientation changes from $\mathrm{N}-\mathrm{S}$ to N100E and N150E (Figure 2a). At the scale of the entire pluton, the foliation pattern reveals an elliptic shape in map view and suggests a sub-vertical funnel geometry. Along the northwest boundary of the Omps pluton, the planar fabric is characterized by a vertical foliation containing a $\mathrm{N} 120^{\circ} \mathrm{E}$ trending stretching lineation marked by elongated enclaves and NE-SW trending aplitic veins that correspond to cross-joints (Feybesse 1981). The northern margin of the Omps pluton is interpreted as a dextral strike-slip fault (Feybesse, 1981).

The Boisset pluton is a southeastward dipping granitic slice with sharp and concordant contacts with the host-rocks. Inside the pluton, the KFM fabric is characterized by a dominant $\mathrm{N}-\mathrm{S}$ trending foliation with steep dips towards the $\mathrm{SE}\left(40^{\circ}\right.$ to $90^{\circ}$ ) and by a NNW-SSE trending, southeast dipping, mineral lineation (Feybesse 1981). In the section perpendicular to the foliation and parallel to the lineation, kinematic indicators such as S-C fabrics, sigma-type porphyroclast systems, sigmoidal biotite or quartz grain oblique shape fabric imply a top-to-the SSE shearing with a dextral 
component (Figure 2b). This kinematics is not in agreement with the left-lateral motion of the SHF. The discrepancy between this normal dextral shearing and the regional sinistral movement of the SHF has been explained as the result of small-scale conjugate shear zones from the main sinistral fault (Feybesse 1981). However, it is worth to note that the sinistral and dextral motions occur in brittle and ductile regimes, respectively, and, as argued below, the two displacements are not contemporaneous.

\subsection{Microstructures}

Several works attempted to define petro-structural criteria to distinguish magmatic or solid-state textures (e.g. Paterson et al. 1989; Bouchez et al. 1990; Passchier and Trouw 1996; Vernon 2000). Based on detail analyses of thirty thin-sections using optical microscope, the microstructures of the Glenat, Omps and Boisset plutons can be divided into three classes (Figures 2 and 4).

Class 1 microstructure is characterized by well-developed crystal faces of early crystallizing minerals such as feldspar and micas, and the lack of extensive dynamic recrystallization of minerals. Crystal-plastic deformation is absent, as indicated by quartz grains with weak undulose extinction only or rare subgrain boundaries. Plagioclase crystals exhibit concentric igneous zonation, and most of them have euhedral to subhedral crystal habits (Figures $2 \mathrm{c}$ and d), indicating that the rock did not experience significant high-temperature subsolidus strain and recrystallization. In Class 1, the magmatic fabrics are well preserved with pristine igneous textures, showing that the mineral orientations developed in the rocks during magma crystallization and were not subsequently deformed 
under solid-state conditions. Most of the northern part of the Glénat pluton and the central part of the Omps pluton belong to this class (Figure 4).

Class 2 microstructure corresponds to weak solid-state deformation. These rocks show evidence of high-temperature plastic deformation features, such as quartz grains partly replaced by subgrains with a chess board pattern, and kinked but stable biotite (Figure 2e). High temperature deformation features such as high-angle sub-grain boundaries and small sized recrystallized new grains are common. This microstructure developed in the transitional rheological state between magmatic and solid states. The southern part of the Glénat pluton and the northwestern margin of the Omps pluton (Figure 4) constitute the most important areas where Class 2 microstructure can be observed.

Class 3 microstructure occurs in protomylonitic to mylonitic bands where intense solid-state deformation is easily recognized in the field since the rock exhibits welldeveloped planar and linear fabrics (Figure 2f). At the thin section scale, biotite and quartz grains are organized in ribbons forming a gneissic texture. The primary quartz grains, are recrystallised and replaced by aggregates of small sized neograins, elongated in the same direction and with serrated grain boundaries. Biotites are intensely deformed with a "mica-fish" shape. Feldspar often displays intense undulose extinction. Class 3 microstructure characterizes the entire Boisset pluton, and it can be also observed in the southern tail of the Omps pluton, however, there the mylonitic fabric is often erased and overprinted by a cataclastic texture. More locally, meter scale mylonitic shear zones are developed in the northern and western parts of the Omps pluton (Figure 4). 


\section{New U-Th-Pb chemical dating}

Previous geochronological data on the Glénat, Omps and Boisset granitic plutons yielded $\mathrm{Rb} / \mathrm{Sr}$ whole rock ages of $272 \pm 4 \mathrm{Ma}, 270 \pm 15 \mathrm{Ma}$ and $281 \pm 10 \mathrm{Ma}$, respectively (Vivier and Lasseyre 1973). In light of modern geochronology, these results appear quite young and poorly reliable, because the age determinations have been performed on whole rock using several analyses to derive an isochron. As the age constraint is essential for the understanding of the emplacement of the three plutons in their regional tectonic frame, new datings have been undertaken using single grain and in situ techniques.

In-situ U-Th-Pb chemical dating of monazite by EPMA combined with microstructural and petrographic analyses has been successfully applied to constrain the timing of pluton emplacement or metamorphic processes (e.g. Suzuki and Adachi 1991; Montel et al. 1996; Cocherie et al. 2005; Be Mezème et al., 2005, 2006a; Cocherie and Legendre 2007). A similar methodology as that presented in the above-cited works has been used in the case of the Glenat, Omps and Boisset plutons.

\subsection{Analytic procedure}

Monazite grains are directly investigated with respect to their textural environment in thin section (Williams and Jercinovic 2002). Scanning electron microprobe (SEM) in back-scattered electron mode allows avoiding micro-inclusions, altered domains and all other components of non-monazite composition. SEM images commonly show heterogeneous domain compositions, which can be related either to 
discrete age domains or to variations of Th and $\mathrm{U}$ composition during the various stages of recrystallisation of monazite within a period of less than 1 Ma.

Monazite grains were analyzed with a Cameca SX 50 electron microprobe. For the detailed analytical procedure, see Cocherie et al. (1998). According to this procedure, detection limit $(2 \sigma)$ is about $150 \mathrm{ppm}$ for $\mathrm{Pb}$ and $\mathrm{U}$; this value is, therefore, taken as the standard deviate of the analysis. A systematic relative error of $2 \%$ is considered for Th as well as for $\mathrm{U}$ concentrations above $7500 \mathrm{ppm}$, in order to avoid an unrealistic low error for U-enriched grains. We used EPMA Dating, a Microsoft Excel add-in software (Pommier et al., 2002), to determe U-Th-Pbtotal ages from EPMA measurements. This program calculates an age for each individual point analysis from raw data. Individual analyses of poorer quality because of their major oxide composition and the maximum acceptable errors were rejected. All the parameters needed for calculating mean and intercept ages are computed and grouped in a specific table ready for plotting with the ISOPLOT program (Ludwig 1999).

The starting assumptions of the chemical $\mathrm{U}-\mathrm{Th} / \mathrm{Pb}$ dating method on monazite are: i) common $\mathrm{Pb}$ is negligible as compared to the amount of thorogenic and uranogenic $\mathrm{Pb}$; ii) no radiogenic $\mathrm{Pb}$ loss occurred since closure of the system; iii) a single age is assumed at each individual spot analysis. Considering monazite, after many cross-checks with conventional isotopic $\mathrm{U}-\mathrm{Pb}$ age determinations (e.g. Montel et al. 1996; Cocherie et al. 1998) it is now accepted that the EPMA spatial resolution allows avoiding inclusions and altered domains that could provide most of the common $\mathrm{Pb}$. Thus, the first assumption of negligible common $\mathrm{Pb}$ can be accepted as true in monazite. Similarly for the second assumption, monazite appears to be a very robust reservoir for radiogenic $\mathrm{Pb}$ 
(cf. the recent experimental work by Cherniak et al. 2004). Cocherie et al. (1998) have shown that when no hydrothermal fluid interacts with the mineral, $\mathrm{Pb}$ diffusion remains insignificant, even for complex polygenetic monazite (Montel et al. 1996, 2000; Braun et al. 1998; Finger et al. 1998; Williams et al. 2001; Williams and Jercinovic 2002). Because of its higher spatial resolution, EPMA is the most efficient method to avoid mixed-age domains. Finally, the MSWD calculation must agree with the Wendt and Carl (1991) criteria to certify the statistical significance of the calculated average age.

\subsection{Sampling}

Each pluton has been sampled for the geochronological study, see location in Figure 6.. These specimens present a common mineral composition of quartz, plagioclase, K-feldspar, biotite, zircon, apatite, monazite, xenotime, ilmenite, hematite and muscovite. Monazite is found as inclusions either in biotite or in feldspar. Analyzed monazite grain sizes are comprised between 50 and $100 \mu \mathrm{m}$. The hand observations of Glénat and Omps plutons do not show any macroscopic mineral preferred orientation. Under the microscope, in the dated specimens, quartz grains reveal some weak undulose extinction and are almost free of sub-grain boundaries. Biotites are not deformed. Ductile deformation is totally absent in feldspars and compositional zoning of plagioclase is locally observed. These mineral microstuctures lack of any solid-state deformations and appear as characteristic of a magmatic flow. Conversely, the Boisset specimen (B63) shows severe intracrystalline plastic deformation. Quartz grain size reduction due to dynamic recrystallization is well developed. The neograins are arranged in a ribbon pattern and exhibit often an oblique shape fabric. Highly sheared biotites anastomose around the weakly deformed but recrystallized K-feldspar porphyroclast. SEM 
observations (Figure 5) are consistent with the optical observations. None of these monazite types exhibit any zoning. Therefore, the obtained date can be confidently considered as the crystallization age of the Glenat, Omps and Boisset granitic magmas coeval with their emplacement time.

\subsection{Results}

EPMA $\mathrm{U}, \mathrm{Th}$ and $\mathrm{Pb}$ data processing is described in detail in Cocherie and Albarède (2001) and Cocherie et al. (2005). The Th/Pb vs. U/Pb plot is used to represent the results (Cocherie and Legendre 2007). The large range of $\mathrm{Th} / \mathrm{U}$ allows the regression line to be well defined. The mean age is calculated using the population centroid where the precision is optimal. The data from the monazite of three different plutons are plotted in Figure 6.

The mean age of the Glénat granitic pluton calculated at the population centroid for 5 grains and 92 analyzed points, from specimen G14, is $320.8 \pm 4.5 \mathrm{Ma}$. The regression line fits quite well the theoretical isochron. As a consequence, the calculated intercepts $\mathrm{Th}-\mathrm{Pb}$ and $\mathrm{U}-\mathrm{Pb}$ ages are concordant at $323+13 /-12 \mathrm{Ma}$ and $299+120 /-132$ Ma. This demonstrates that the regression line is not a mixing line between two populations of different compositions but corresponds to the crystallization of the analyzed monazite grains.

The Omps pluton (O17) yields an isochron age of $331.5 \pm 3.5 \mathrm{Ma}$ which is calculated at the centroid of the population using 158 analyses obtained on 8 grains. The intercept ages are similar within error $(\mathrm{U}-\mathrm{Pb}$ and $\mathrm{Th}-\mathrm{Pb}$ ages of $369+66 /-69 \mathrm{Ma}$ and 328 $\pm 7 \mathrm{Ma}$, respectively). 
Seven monazite grains were analyzed from the Boisset pluton (B63). The regression line is parallel to the reference isochron, and the two $\mathrm{U}-\mathrm{Pb}$ and $\mathrm{Th}-\mathrm{Pb}$ intercept ages of $378+175 /-195$ and $315+12 /-11$ Ma are similar within errors. At the centroid of the population, a mean age has been calculated at $318+/-3 \mathrm{Ma}$. The calculated MSWD of each analyzed specimen are in agreement with such an interpretation (Wendt and Carl 1991). The Glénat and Boisset plutons yield similar ages of ca. $320 \mathrm{Ma}$, the age of the Omps pluton appears older than the other two.

\section{Geophysical data}

\subsection{Magnetic fabrics}

The Anisotropy of Magnetic Susceptibility (AMS) of rocks is controlled by preferred orientation of magnetic mineral grains, and therefore AMS provides information on both the grain magnetic susceptibilities and the grain orientations. The AMS is a powerful tool to investigate the internal structure of plutons where the macroscopic preferred mineral orientation is absent (e.g. Hrouda 1982; Jackson and Tauxe 1991; Tarling and Hrouda 1993; Borradaile and Henry 1997; Bouchez 1997, 2000; Borradaile and Jackson 2004). Hence, together with textural information, AMS method allows to study fabrics which have recorded regional deformations that were imposed on the crystallizing magma and on the cooling rock. Fabrics give information on regional tectonics and local deformation (e. g. Benn et al. 1998; Pignotta and Benn 1999; Benn et al. 2001). The bulk magnetic susceptibility of a rock depends on the intrinsic magnetic susceptibilities and proportions of the rock-forming minerals (Borradaile and Jackson, 2004). 
In the study area, 51 sites of 248 oriented cores have been drilled for AMS study. When it was possible, the cores were oriented in the field using both magnetic and sun compasses. The mean difference between magnetic and sun azimuths was less than $0.5^{\circ}$. The cores were cut into the standard specimens of $22 \mathrm{~mm}$ in length and $25 \mathrm{~mm}$ in diameter. Hysteresis loop method was used to identify the magnetic mineral composition of each representative plutons (Borradaile et al; 2008 and references therein). Three hysteresis loops on each representative specimen of pluton were acquired using a translation inductometer within an electromagnet providing a field of up to 1 Tesla in the Paleomagnetic laboratory of IPGP at Saint Maur (Figure 7). A dominant effect of paramagnetic minerals is demonstrated by the almost perfect linear variation of induced magnetization. Thus, it can be considered that biotite, as a paramagnetic mineral, is the main AMS carrier for the Glénat, Omps and Boisset plutons. The ferromagnetic phases, if exist, should be in a small proportion relatively to other minerals and do not influence AMS results as the measured specimens show rather low magnetic susceptibility (Figure 8). The specimens were analysed using an AGICO Kappabridge KLY 3S apparatus in the Laboratory of Rock Magnetism of Orléans University. The three principal axes of the AMS ellipsoid $K_{1} \geq K_{2} \geq K_{3}$ were calculated after measurements for each specimen with a corresponding confidence interval at the 95\% level by Jelinek's statistic method (1978; Table 1).

For all of three plutons, the magnetic susceptibility $\left.\left(\mathrm{Km}=\mathrm{K}_{1}+\mathrm{K}_{2}+\mathrm{K}_{3}\right) / 3\right)$, varies weakly from 50 to $220 \mu \mathrm{SI}$ and shows an unimodal distribution. The averages of magnetic susceptibility, $\mathrm{Km}$, are of $113 \pm 37 \mu \mathrm{SI}(1 \sigma), 107 \pm 16 \mu \mathrm{SI}$ and $118 \pm 20 \mu \mathrm{SI}$ for the Glénat, Omps and Boisset plutons, respectively. These weak values (lower than 
$150 \mu \mathrm{SI}$ ) are typical of granites for which the main carriers of AMS are paramagnetic phases such as micas, amphiboles or cordierite (e.g. Ellwood and Wenner 1981; Zapletal 1990; Bouchez 1997).

For rocks whose AMS is dominated by weakly anisotropic paramagnetic silicates the symmetry of AMS maybe a more faithful reflection of petrofabric symmetry, although this can depend on the symmetry of the dominant minerals. This is an influence of crystal symmetry on magnetic properties, independent of any tectonic effect (Borradaile and Henry, 1997; Borradaile et al; 1999).

To describe the degree of anisotropy and shape of the AMS ellipsoid, the $\mathrm{Pj}$ and $\mathrm{T}$ parameters (Jelinek 1981) were calculated for each AMS site with $\mathrm{Pj}=\exp \left\{2\left[\left(\ln \mathrm{K}_{1^{-}} \ln \right.\right.\right.$ $\left.\left.\mathrm{Km})^{2}+\left(\ln \mathrm{K}_{2}-\ln \mathrm{Km}\right)^{2}+\left(\ln \mathrm{K}_{3}-\ln \mathrm{Km}\right)^{2}\right]\right\}^{1 / 2}$ and $\mathrm{T}=\left[2 \ln \left(\mathrm{K}_{2} / \mathrm{K}_{3}\right) /\left(\ln \left(\mathrm{K}_{1} / \mathrm{K}_{3}\right)\right]-1\right.$. The shape parameter $\mathrm{T}$ indicates whether the fabric ellipsoid is prolate $(0>\mathrm{T} \geq-1)$ or oblate $(0$ $<\mathrm{T} \leq 1$ ). The majority of sites (46 out of 51 ) show an oblate AMS ellipsoid (Figure 9) with only 5 sites displaying T values smaller than 0 . Nevertheless, it is worth to note that when comparing the degree of anisotropy $\mathrm{Pj}$ (Figure 10) with shape parameter $\mathrm{T}$ of the AMS ellipsoid (Figure 11a), although $\mathrm{T}$ values remain in a similar range for three plutons, $\mathrm{Pj}$ increases from the Glénat (mean $\mathrm{Pj}=1.012)$ to the Omps (mean $\mathrm{Pj}=1.047)$ and eventually to the Boisset granitic facies (mean $\mathrm{Pj}=1.065$ ). Conversely, no clear relationship between Km and T may be observed (Figure 11b; Borradaile and Henry 1997). No spatial correlation between the magnetic susceptibility (Figure 8) and the degree of anisotropy (Figure 11a) does really exist. Variations of Pj are likely partly related to the magnetic mineralogy (Borradaile and Henry, 1997). 
Concerning the AMS directional distribution, more than $88 \%$ of sampled sites reveal at least one well-defined axis with a confidence level less than $20^{\circ}$ (Jelinek 1978, Figures 12 and 13). If the confidence level of a magnetic axis, $\mathrm{K}_{1}$ and/or $\mathrm{K}_{3}$, is larger than $20^{\circ}$ within a site, this magnetic axis is considered as poorly defined, and thus, the siteaverage orientation is not reliable (Table 1). In detail, four groups of sites can be distinguished. Namely, group I (41\%) is characterized by three well clustered axes (e.g. Sites 19 and 40 in Figures 12 and 13), group II (6\%) corresponds to the sites where $\mathrm{K}_{1}$ is better defined than $\mathrm{K}_{2}$ and $\mathrm{K}_{3}$ (e.g. Site 4 in Figure 12), group III (41\%) shows the opposite case to group II, $\mathrm{K}_{3}$ is better clustered than other two axes (e.g. Site 25 in Figure 13), group IV (12\%) presents three scattered axes (e.g. Site 33 in Figure 12). The magnetic lineation (parallel to $\mathrm{K}_{1}$ ) and foliation (normal to $\mathrm{K}_{3}$ ) for each site were computed from the averages of the $\mathrm{K}_{1}$ and $\mathrm{K}_{3}$ orientations of individual specimens. Since the SHF separates the Glénat pluton from the Omps and Boisset ones, AMS measurements are described separately.

\section{Glénat pluton}

In the Glénat pluton, the well-defined magnetic foliations (Figure 14a) are close to horizontal. The calculated average pole of the magnetic foliation for the whole pluton lies at $\mathrm{N} 220^{\circ} \mathrm{E}$ dipping at $72^{\circ}$ towards the southwest with a maximum density of $15.38 \%$ $(\mathrm{n}=27)$. The magnetic lineations are less clustered (Figure 14b), but dominant E-W trending and eastward dipping $\left(12^{\circ}\right)$ magnetic lineation is observed with a maximum density of $9.5 \%$ for 27 analyzed sites. 


\section{Omps pluton}

To the east of the SHF, the magnetic fabrics of the Omps pluton are characterized by sub-vertical magnetic foliations with variable strikes (Figure 14a). Most of the magnetic foliation poles are weakly inclined with a dip less than $20^{\circ}$ (14 out of 16 sites). On the northwestern part of the pluton, the magnetic foliation is well defined. The strike of the magnetic foliation is NW-SE in the northern part, whereas on the western part, along the SHF, the magnetic foliation is trending N-S. In its southern part, a magnetic NW-SE trending foliation with vertical dips dominates, while to the east, the magnetic foliation trends N-S. In agreement with the K-feldspar fabrics, the AMS results of the Omps pluton indicate a concentric shape of the foliation. Three distinct magnetic lineation orientations can be recognized within the Omps pluton (Figure 14b): the first one, observed ubiquitously throughout the pluton trends NW-SE and dips weakly northwestwards $\left(6^{\circ}\right)$, the second one, which is found in the core and eastern part of the pluton, exhibits also a NW-SE trend but with a steeper plunge (ca. $60^{\circ}$ ), and the third one, restricted along the SHF, corresponds to a subhorizontal N-S direction.

\section{Boisset pluton}

In the Boisset pluton, the magnetic fabric is characterized dominantly by a NNESSW trending, steeply plunging to the ESE foliation, and a NNW-SSE trending, southward dipping (less than $20^{\circ}$ ). This magnetic fabric pattern correlates well with the previous measurements of MFK preferred orientation carried out directly in the field (Feybesse 1981) and complies with our own field observations). 
As paramagnetic minerals, such as mica, are considered as the main AMS carriers, the above described AMS orientations of magnetic fabrics should be normal ones (Rochette et al., 1992, 1999).

\subsection{Gravity data}

The gravity method has proven its efficiency for 3D imaging of geological structures and particularly for the study of plutons (e.g. Vigneresse and Brun 1983; Brun et al. 1990, Martelet et al. 2004). In the study area, the French gravity database presents important gaps of data (Figure 15); that is the reason why 310 new gravity stations were measured with a SCINTREX CG3-M micro-gravimeter. A final coverage of the study area is achieved by one station per square kilometer (Figure 15). All measurements were tied to the CGF65 French gravity reference network and the gravity anomaly was computed with respect to the theoretical value of gravitational acceleration on Hayford-1930 ellipsoid (Torge, 2001 and references therein). In order to obtain the complete Bouguer anomaly, we successively performed standard free air, plateau and terrain corrections. Terrain corrections were computed up to $167 \mathrm{~km}$, following the procedure detailed in Martelet et al. (2002). In order to be close to the expected density of the granites, a $2600 \mathrm{~kg} \cdot \mathrm{m}^{-3}$ Bouguer reduction density was chosen. The gravity data were finally interpolated using a standard minimum curvature algorithm, resulting in a 500-m anomaly grid. Taking into account mostly the accuracy of positioning (roughly $1 \mathrm{~m}$ on IGN benchmarks), as well as the error on terrains corrections (Martelet 1999; Martelet et al. 2002), and on the gravity measurement itself, the average uncertainty of the dataset, computed as the weighted sum of the cumulative errors, is close to $0.5 \mathrm{mGal}\left(1 \mathrm{mGal}=10^{-5} \mathrm{~m} \cdot \mathrm{s}^{-2}\right.$ in SI unit). Interpolation of these data together with old less 
accurate data increases the average accuracy level of the Bouguer map to about $1 \mathrm{mGal}$. Considering that we are mainly interested in the geometry of relatively shallow granitic bodies, the long wavelengths of the Bouguer anomaly, corresponding to deep density contrasts (such as the Moho), were removed from the signal. In the study area, a sharp E-W regional gradient can be observed in the French gravity map, that we appropriately matched using a low-pass filter of Gaussian-type with a cutoff wavelength of $300 \mathrm{~km}$ over the entire Massif Central. The resulting residual Bouguer anomaly in the study area (Figure 15) represents the effect of density heterogeneities located below the topography, down to a few kilometers.

To the first order, the negative Bouguer anomalies (Figure 15) can be correlated to the three granitic plutons. The most intense negative anomaly on the northwestern part of the map suggests thickening of the Glénat pluton. In contrast, the Omps and Boisset pluton may not be very thick as they are not associated to intense negative gravity anomaly. Furthermore, it should be noted that the gravity anomaly next to Boisset pluton is shifted towards the northeast, implying that the Boisset massif may spread northeastwards at depth. To the east, previous studies (Olivier and Améglio 2002) showed that the Marcolès and Veinazès plutons are characterized by marked negative anomalies suggesting that the granitic rocks become thicker to the SE. However, our observations as well as previous gravity studies and structural constraints in the host rocks, preclude any link at depth between these plutons (Olivier and Améglio 2002). To the west of the SHF, the "Millevaches" leucogranites seem to be shallow as they are not associated to negative anomalies. To the northeast of the Omps massif, the Lower Gneiss Unit is characterized by a positive anomaly, which confirms that 
these units are dense and that the low density Tertiary sedimentary cover upon the LGU is thin.

\section{Geological and geophysical modelling}

\subsection{Preliminary 3D geological model}

In order to assess the rooting of granites and their relationships with the SHF, a 3D geological modelling was performed, further constrained by 3D gravity inversion. Primarily, the 3D modelling requires the consistency of all available data; it also allows to integrate the data in a common geometrical referential, and thus to merge them into a geological model that supports the 3D structural interpretation. The 3D preliminary model of the study area has been achieved using the geological map, including lithological boundaries, and field structural data, as well as the AMS foliation in granitic rocks. For this purpose, we used the "3D Geomodeller" software (Aug 2004; Guillen et al. 2004; Martelet et al. 2004), which reproduces 3D geological geometries based on interpolation of a scalar field in space (Lajaunie et al. 1997; Chilès et al. 2004), where a lithological contact corresponds to an isovalue of this field and the dipping of the structures corresponds to the gradient of this field. The topological relationships between the different lithological units and the geometrical relationships, like superposition, intrusion or cross-cutting relations, are taken into account through a "lithological pile", in order to reproduce complex geological systems as realistically as possible. A $28 \mathrm{x}$ $35 \times 8 \mathrm{~km}$ 3D model of the regional geology was thus interpolated. This model is preliminary since no constraints have been introduced yet concerning the depth of geological bodies. At this stage, the geometry derives from a geostatistical extrapolation 
of surface geological observations of contacts and dips. In a second step, inverse modelling of the Bouguer gravity anomaly was performed in order to refine the preliminary 3D geology, especially the three plutons.

\subsection{Gravity inversion}

In order to improve the geometrical models realized above, a 3D gravity inversion has been carried out. We used a statistical formulation of the inverse problem (Guillen et al. 2000, 2008; Bosch et al. 2001). This inversion scheme is particularly adapted to refine existing models since a realistic and topologically consistent starting model is needed in order to achieve a meaningful convergence of the inversion process. Being part of 3D GeoModeller software, the inversion algorithm is designed to investigate the space of possible density models following a Monte-Carlo algorithm (Guillen et al. 2006). The inversion process is briefly explained here and we refer to Guillen et al. (2004, 2006, 2008) for a thorough description of the method.

In order to compute the gravity effect of the 3D model, the starting geometrical model is discretized into 3D elementary voxels. Densities of the different units of the study area were taken from previous works in nearby areas (Améglio et al. 1997; Olivier and Améglio 2002; Talbot et al. 2005b; Gébelin et al. 2006) as well as some new density determinations. In order to constrain stochastic inversion, density distributions were expressed as mean density and standard deviation (Table 2). Starting from the preliminary $3 \mathrm{D}$ geometrical model, $5 \times 10^{6}$ different models were successively generated following a Monte-Carlo progression (Mosegaard and Tarantola 1995). The convergence of the process is achieved reducing the Root Mean Squared (RMS) difference between 
the model gravity effect and the Bouguer map. Modifications of the initial model address both the geometry and the density of geological bodies. The density modifications follow the a priori density distribution law (average and standard deviation), and the overall topology of the initial model is conserved, i.e. no geological bodies are added or removed and voxels at the surface are not modified, with respect to the reference geological map. Following these rules, at each iteration, either the lithological attribute or the density of a voxel is modified, and the gravity effect of the 3D model is re-computed.

All models with RMS misfit inferior or equal to $1 \mathrm{mGal}$ are memorized and statistically combined into a most probable model. This threshold of $1 \mathrm{mGal}$ has been chosen with respect to the average accuracy of the Bouguer anomaly map, as mentioned earlier. The result is provided in terms of probability of presence of densities in the $3 \mathrm{D}$ space.

In Figure 16, two NW-SE and one SW-NE cross-sections, cutting across the SHF, have been extracted from the inverted 3D most probable model. Since most density contrasts principally occur at the granitic pluton- metamorphic host rocks interface, the density cross-sections extracted from the 3D inverted model are representative of the pluton bulk geometry and of their geometric relationships with the metamorphic host rocks. The basement associated to high densities is represented in redish colors, whereas the low densities in blueish colors, represent the plutons, the leucogranites and the sedimentary cover. The inverted cross-sections show an overall consistency with the starting 3D geometrical model (black line in Figure 16). Initial geological bodies are diversely deformed after inversion, but none of these deformations significantly modify the understanding of the geology. The NW-SE cross-section (Figure 16a) shows that to 
the northwest, the low densities associated to the Millevaches Massif are shallow and the leucogranite pluton does not exceed $1 \mathrm{~km}$ at depth. The Glénat pluton clearly deepens northwestwards with a 4-km maximum thickness. To the east of the SHF, the Boisset pluton is very shallow, as it does not reach more than $500 \mathrm{~m}$ in depth. In the same way, the Marcolès pluton exhibits a $1 \mathrm{~km}$ flat-lying shape, and does not reveal any root on this NW-SE profile. To the Southeast, the Veinazès pluton reaches a ca. $1.5 \mathrm{~km}$ depth, which is in good agreement with Olivier and Améglio (2002) results. The NW-SE cross-section (Figure 16b) confirms that, to the northwest, the Glénat pluton thickens northwestwards down to $2.5 \mathrm{~km}$. To the southeast, the Omps pluton does not exceed $1 \mathrm{~km}$ of thickness. The SW-NE cross-section (Figure 16c) does not reveal significant modifications compared to the initial geological model. To the southwest, the dense metamorphic rocks occupy a wide area. In this SW-NE direction, the Glénat pluton presents a laccolitic shape, with a constant thickness around $1.5 \mathrm{~km}$, but does not show any deepening corresponding to a possible root zone. To the East of the SHF, the Omps pluton has an average $1.5 \mathrm{~km}$ thickness, lower than the $2.5 \mathrm{~km}$ suggested by extrapolation of surface dips, in the preliminary model. At the NE end of the cross-section, a shallow sedimentary cover directly overlies the dense LGU.

\section{Discussion}

The lack of zonation within the analyzed monazite grains indicates that monazite crystallized in the magma. The U-Th-Pb chemical ages of ca $321 \pm 5 \mathrm{Ma}, 332 \pm 4 \mathrm{Ma}$ and $318 \pm 3$ Ma yielded by the Glénat, Omps and Boisset plutons, respectively, show that these plutons emplaced in Middle to Late Carboniferous times. Although the Omps 
pluton appears as ca $10 \mathrm{Ma}$ older than the other two, the petrological similarities and the spatial proximity of the Boisset and Omps plutons suggest that these plutons emplaced from late Visean to Namurian during the same tectono-metamorphic event. The tectonic setting of the Middle to Late Carboniferous magmatic event in the FMC has already been described (e. g. Faure 1995; Faure et al. 2005). Therefore, a similar tectonic setting seems likely to account for the emplacement of all these plutons.

As shown by the structural studies, the dominantly flat-lying foliation of the Glénat pluton developed under sub-solidus conditions for most of the massif, and under high-temperature solid-state conditions on the pluton southern extremity. In both domains, E-W to NW-SE trending magnetic lineations are widespread (Figure 14b) and are parallel to the stretching lineations measured in the contact aureole.

The Omps pluton is characterized by a magmatic fabric in its centre and by a weak solid-state one in its western and northeastern parts. The main part of the pluton exhibits a square-shape with concentric high-angle dipping foliations. On the western and northern pluton margins, the low angle dip magnetic lineation trends N-S and NW-SE, respectively. Conversely, the central and eastern parts of the Omps pluton are characterized by highly dipping magnetic lineation.

The Boisset pluton records a conspiscuous solid-state deformation and is characterized by a N-S trending and eastward dipping magnetic foliation and a welldefined NNW-SSE trending and southward plunging lineation. During its emplacement at $\sim 318 \mathrm{Ma}$, the Boisset pluton developed a metamorphic aureole in the country rock. The contact metamorphic minerals are synkinematic and display shear criteria such as asymmetric strain shadows or recrystallisation tails (cf. section 3). Those kinematic 
indicators are consistent with a normal-dextral motion of the country rock coeval with the Boisset pluton emplacement.

The AMS measurements obtained from granitic rocks showing magmatic fabrics are consistent with the K-feldspar preferred orientation (Feybesse 1981). A NW-SE magnetic lineation predominates in these granitoids. Taking into account its limited thickness (about $1.5 \mathrm{~km}$ ) provided by gravity inversion, and its quadrangular shape, the Omps pluton appears as a horizontal "rectangular prism". The highly dipping concentric foliation complies with the bulk shape of the massif. The granite fabric is dominated by magmatic textures in the core and eastern margin, whereas, weak solid-state fabrics characterize the northern and western margins. These fabrics appear to develop during pluton emplacement. The highly plunging magmatic lineation in the central part can be interpreted as the result of magma ascent. On the contrary, a N-S and NW-SE trending sub-horizontal magmatic lineation develops on the western and northern margins, respectively. These linear fabrics apparently reflect shearing along these margins of the pluton during its emplacement.

In order to achieve a regional geological description of the relationships between Glénat, Omps and Boisset plutons and the SHF, AMS and field observations were merged into a 3D model. The refinement by gravity stochastic inversion provides the geometric frame of a 3D geological model which (i) agrees with the surface geological data, (ii) is constrained by the gravity and AMS geophysical data, (iii) has a true statistical reliability. Though certainly non-unique, the obtained 3D inverted model provides an integrated view of the three granitic massifs and their relationships with the 
host-rocks. Some geological implications of the model are discussed in the following paragraph.

The Glénat massif roots to the northwest, and spreads out to the southeast. The Omps and Boisset plutons are ca. $1 \mathrm{~km}$ thick laccoliths. Despite their cartographic proximity, none of these three plutons root in the SHF. Furthermore, the subsolidus or post-solidus fabrics developed in these plutons are not in agreement with the SHF Stephanian brittle kinematics. In the southern part of the MCF, if the SHF was active during the Namurian, the NW-SE stretching recorded by the surrounding country rocks and plutons would rather support a normal fault setting. Therefore, neither genetic nor structural link between the SHF, at least in its present trace, and the plutons can be inferred from either the internal structure or the shape of the pluton. Moreover, our results suggest the opportunistic nature of the emplacement of these plutons in the vicinity of the SHF instead of a structural relationship. This result is quite different from what was demonstrated in the Montmarault area, in the northern part of the SHF, where an apparent dilatant behaviour of the fault could be inferred from gravity, magnetic and AMS studies (Joly et al. 2007, 2008). The early Late Carboniferous (ca. 320 Ma) Montmarault pluton exhibits a flat-lying foliation and a NW-SE trending mineral lineation that steepens to the East towards the SHF. Gravity modelling indicates that the maximum thickness of the Montmarault pluton is located along the SHF. From these lines of evidence, it has been argued that the SHF corresponded to a feeder zone for the Montmarault pluton (Joly et al. 2007, 2008). Although a structural? link between the pluton and the fault is not strictly demonstrated, it can be proposed that if the SHF existed at the time of the Montmarault pluton emplacement, i.e. at $320 \mathrm{Ma}$, this fault should have behaved as a normal fault, or a 
kind of crustal scale tension crack. Moreover, considering the important scale of the fault (Joly et al. 2007, 2008), the SHF is likely to have experienced various rheological behaviours (i.e. brittle or ductile) and various kinematics (i.e. wrench or normal motions) along distinct segments. Furthermore, as a $350 \mathrm{~km}$ long fault, the SHF might have not existed in its southern part in the Namurian or Westphalian, but appeared only during the Stephanian sinistral strike-slip tectonics.

The tectonic significance of the present multidisciplinary study of these three granitic massifs can be better understood in the regional tectonic framework of the southern FMC (Figure 18). It is already well established that numerous granodioritic and leucogranitic plutons of Namurian to Westphalian age (325-315Ma) throughout the southern part of the FMC are syntectonic bodies that recorded the late orogenic ductile NW-SE extension (Faure et al. 1992; Faure 1995; Talbot et al. 2004, 2005a, 2005b; Be Mezème et al. 2006b). The Margeride pluton is one of the largest porphyritic monzogranitic pluton in the FMC. On the basis of petro-structural, AMS and gravimetric analyses, it has been shown that this huge massif emplaced through NE-SW trending feeder zones interpreted as extensional fractures connected by sinistral NW-SE trending transtensional jogs (Talbot et al. 2005b). In the Cévennes area, the Mt-Lozère-Borne and Aigoual-St-Guiral plutons also record a NW-SE to E-W trending AMS lineation which is parallel to the mineral and stretching lineation observed in the host-rocks (Figure 17; Talbot et al. 2004, 2005a). To the East, the NW-SE trend of the maximum stretching direction turns E-W as shown by the magnetic lineation measured in the Mt-LozèreBorne, Aigoual-St-Guiral, and Rocles plutons. 
To the West of the Margeride pluton, the emplacement of the Veinazès and Marcolès plutons in transtensional jogs opened along ENE-WSW-trending sinistral wrench faults plutons has been proposed (Olivier and Améglio 2002). However, no field or AMS evidence neither for NE-SW nor NW-SE trending wrenching support this view. Thus, on the basis of the magmatic texture of the monzogranite, the dominant NW-SE mineral and magnetic lineation, and the shape of the gravity anomaly, an alternative interpretation suggested that the Veinazès pluton emplaced in a NE-SW km-scale tension gash opened as a result of NW-SE-oriented extension (Faure 1995; Talbot et al. 2005b). This NW-SE opening direction is in agreement with the regional syn-orogenic Namurian extension

The Glénat pluton exhibits a domal shape with an E-W trending lineation developed under magmatic or high-temperature solid-state, during its emplacement. Moreover, it must be kept in mind that when the Glénat pluton acquired its fabric, at ca. $321 \mathrm{Ma}$, this body was located about $80 \mathrm{~km}$ north of its present location, taking into account the restoration of the Stephanian left lateral offset of the SHF. Unfortunately, the counter part of the Glénat pluton, east of the SHF, is presently hidden below the Tertiary deposits. Nevertheless, at the scale of the entire Massif Central, the architecture of the Glénat pluton is consistent with that of other Carboniferous plutons (Faure 1995). Consequently, the model established from mineral and magnetic fabrics and gravity observations seems in good agreement with the Middle-Late Carboniferous general NWSE extensional tectonics of the French Massif Central.

In this model, the tectonic setting of the Boisset pluton appears as peculiar since its NNW-SSE trending linear structure deviates from the regional NW-SE trend. This 
lineation is developed under a solid-state rheology. Kinematic indicators observed in the field along the NNW-SSE trending lineation and perpendicularly to the eastward or southeastward dipping foliation, show a top-to-the-S shearing that complies with a ductile normal faulting. Moreover, the N-S trend and eastward dip of the foliation in the hostrocks and the Boisset laccolith is in agreement with gravity data. Thus, the structural accordance between the metamorphic host-rocks and the fabric of the plutonic rocks argue for a pluton emplacement in a tectonic setting. The magnetic lineation of the Boisset massif cannot be attributed to the Stephanian left-lateral shearing related to the motion of the SHF since the ductile shearing is of opposite sense. Moreover, as shown in section 3, the ductile deformation of the Boisset pluton occurred after the magma crystallization, dated at ca. $318 \mathrm{Ma}$, and before the Stephanian brittle episode. Therefore, two possible explanations can be put forward. Firstly, the linear fabric of the Boisset pluton is independent of the regional tectonic regime, or secondly, the normal-dextral shearing corresponds to a local rotation of the regional NW-SE preferred orientation axes, possibly as a result of interference with the proto-SHF. In the present state of knowledge, there is no regional tectonic pattern that might account for such a N-S lineation. Furthermore, the small size of the pluton and its thin laccolithic shape might be responsible for this abnormal lineation trend in agreement with the first hypothesis.

\section{Conclusion}

The history of the Glénat, Omps and Boisset granitic plutons provides significant new insight into the nature and characteristics of fundamental processes responsible for the evolution of the continental crust of the Variscan FMC during early Late 
Carboniferous times. The good consistency in age, petrology and structure indicates that these three plutons underwent the same extensional tectonic regime as that experienced by the crust in the entire FMC. The NW-SE magnetic lineation recorded in the NamurianWestphalian plutons is in agreement with the NW-SE linear trend is also observed in other Carboniferous plutons of the French Massif Central, such as the north Limousin leucogranitic plutons to the NW, Montmarault pluton to the North, Margeride to the Northeast, Veinazès, Mont-Lozère and Aigoual plutons to the East. The difference of ca $40^{\circ}$ of the lineation stretching direction of the Boisset pluton with respect to other two may be due to its small size and post-solidus deformation. The gravity and structural inversion refutes any structural relationships between the SHF and the three studied plutons. Moreover, no ductile shearing has been observed along the SHF in this area. Consequently, the existence of a pre-Stephanian motion of the SHF in the south of the FMC cannot be inferred from the internal fabrics or architecture of the Glénat, Omps and Boisset plutons, contrary to what was shown in the northern part of the SHF with the Montmarault pluton. One possibility is that the proto-SHF did not even exist in the southern part of the FMC during the emplacement of Glénat, Omps and Boisset plutons. However, we shall conclude from this study, and in comparison with other previous ones, that the NW-SE lineation pattern observed in the Glénat and Omps plutons agrees with the Middle to Late Carboniferous extensional regime of the FMC, and that their emplacement may be more controlled by regional tectonics rather than pluton internal dynamics or local structures.

\section{Acknowledgments}


We are grateful to M. Diament for providing us with a SCINTREX CG3-M micro-gravimeter. The 3D Geomodeller team: Antonio Guillen, Gabriel Courrioux, Philippe Calcagno and Intrepid Geophysics team are acknowledged for their support. Geophysical maps were drawn using Geosoft software. J.Y. Roig and J.L. Feybesse are thanked for fruitful discussions. The positive and insightful comments provided by both reviewers F. Hrouda and G. Borradaille are gratefully acknowledged.

\section{References}

Améglio, L., Vigneresse, J.L., Bouchez, J.L., 1997. Granite pluton geometry and emplacement mode inferred from combined fabric and gravity data, In: Bouchez, J.-L., Hutton, D.H.W., Stephens, W.E. (Eds.), 1997. Granite: From Segregation of Melt to Emplacement Fabrics, Kluwer Academic Publishers, Dordrecht, pp. 199-214.

Aranguren, A., Tubia, J.M., Bouchez, J.L., Vigneresse, J.L., 1996. The Guiritz granite, variscan belt of Northern Spain: extension-controlled emplacement of magma during tectonic escape, Earth Planetary Science Letters, 139, 165-176.

Aug, C., 2004. Modélisation géologique 3D et caractérisation des incertitudes par la méthode du champ de potentiel, Ph-D Thesis, École des Mines de Paris.

Be Mezème, E., Faure, M., Cocherie, A., Chen, Y., 2005. In situ chemical dating of tectonothermal events in the French Variscan Belt, Terra Nova, 17, 420-426.

Be Mezème, E., Cocherie, A., Faure, M., Legendre, O., Rossi, Ph., 2006a. Electron microprobe monazite geochronology of magmatic events: Examples from Variscan migmatites and granitoids, Massif Central, France, Lithos, 87, 3-4, 276-288. 
Be Mezème, E., Faure, M., Chen,Y., Cocherie, A., Talbot, J.-Y., 2006b. Structural, AMS and geochronological study of a laccolith emplaced during Late Variscan orogenic extension: the Rocles pluton (SE French Massif Central), International Journal of Earth Sciences, DOI:10.1007/s00531-006-0098-2.

Benn, K., Ham, N.M., Pignotta, G.S., Bleeker, W., 1998. Emplacement and Deformation of Granites During Transpression - Magnetic Fabrics of the Archean Sparrow Pluton, Slave Province, Canada. Journal of Structural Geology, 20, 9-10, 12471259.

Benn, K., Paterson, S.R., Lund, S.P., Pignotta, G.S., Kruse, S., 2001. Magmatic fabrics in batholiths as markers of regional strains and plate kinematics: example of the Cretaceous Mt. Stuart batholith, Physics and Chemistry of the Earth, 26, 343-354.

Blès, J. L., Bonijoly, D., Castaing, C., Gros Y., 1989. Successive post-variscan stress fields in the French Massif Central and its borders (western European plate): Comparison with geodynamic data, Tectonophysics, 169, 79-111.

Bonijoly, D., Castaing, C., 1987. Ouverture et évolution structurale de quelques bassins houillers de directions orthogonales, dans le Massif Central français, Annale de Société géologique du Nord, CVI, 189-200.

Borradaile, G.J., Henry, B., 1997, Tectonic applications of magnetic susceptibility and its anisotropy, Earth-Science Reviews, 42, 1-2, 49-93.

Borradaile, G.J., Werner, T., Lagroix, F., 1999. Magnetic fabrics and anisotropycontrolled thrusting in the Kapuskasing Structural Zone, Canada, Tectonophysics 302, $241-256$. 
Borradaile, G. J., Jackson, M., 2004. Anisotropy of magnetic susceptibility (AMS): magnetic petrofabrics of deformed rocks. In F.Martin-Hernandez, C.M Lünenburg, C. Aubourg \& M. Jackson (Eds.) Magnetic Fabric:Methods and Applications, Geological Society London, Special Publication, 238, 299-360.

Bosch, M., Guillen, A., Ledru, P., 2001. Lithologic tomography: an application to geophysical data from the cadomian belt of northern Brittany, France, Tectonophysics, 331, 197-228.

Bouchez, J.L., Gleizes, G., Djouadi, T., Rochette, P., 1990. Microstructure and magnetic susceptibility applied to emplacement kinematics of granites: the example of the Foix pluton (French Pyrenees), Tectonophysics, 184, 157-171.

Bouchez, J.L., 1997. Granite is never isotropic: An introduction to AMS studies of granitic rocks. In: Bouchez, J.-L., Hutton, D.H.W., Stephens, W.E. (Eds) 1997. Granite: From segregation of melt to emplacement fabrics, Kluwer Academic Publishers. Dordrecht 95-112.

Bouchez, J.L., 2000. Anisotropie de susceptibilité magnétique et fabrique des granites, Comptes Rendus de l'Académie des Sciences, 330, 1-14.

Braun, I., Montel, J.M., Nicollet, C., 1998. Electron microprobe dating of monazites from high-grade gneisses and pegmatites of the Kerala Khondalite Belt, southern India, Chemical Geology, 146, 65-85.

Brun, J.P., Gapais, D., Cogné, J.P., Ledru, P., Vigneresse, J.L., 1990. The Flamanville granite (NW France): an unequivocal example of an expanding pluton, Geological Journal, 25, 271-286. 
Burg, J.-P., Brun, J.-P., Van Den Driessche, J., 1990. Le sillon houiller du Massif Central Français: Faille de transfert pendant l'amincissement crustal de la chaine varisque? Comptes Rendus de l'Académie des Sciences Paris, Serie II, 311, 147-152.

Burg, J.P., Van Den Driessche, J., Brun, J.P., 1994. Syn-to post thickening in the Variscan Belt of the Western Europe: modes and structural consequences, Géologie de la France, 3, 33-51.

Castro, A., 1986, Structural pattern and ascent model in the Central Extremadura Batholith, Hercynian Belt, Spain, J. Struct. Geol., 8, 633-645, doi: 10.1016/01918141(86)90069-6.

Clemens, J.D., and Mawer, C.K., 1992, Granitic magma transport by fracture propagation, Tectonophysics, 204, 339-360.

Crawford, M.L., Klepeis, K.A., Gehrels, G., Isachsen, C., 1999, Batholith emplacement at midcrustal levels and its exhumation within an obliquely convergent margin, Tectonophysics, 312, 57-78, doi: 10.1016/S0040-1951(99)00170-5.

Cherniak, D.J., Watson, E.B., Grove, M., Harrison, T.M., 2004. Pb diffusion in monazite: a combined RBS/SIMS study, Geochimica et Cosmochimica Acta, 628, 829840.

Chilès, J.P., Aug, C, Guillen, A., Lees, T., 2004. Modelling the Geometry of Geological Units and its Uncertainty in 3D From Structural Data: The Potential-Field Method, extended abstract in: Orebody Modelling and Strategic Mine Planning, 2224/11/2004, Perth, Australia.

Cocherie, A., Legendre, O., Peucat, J.J., Kouamelan, A.N., 1998. Geochonology of polygenetic monazites constrained by in situ electron micropobe Th-U-total lead 
determination: Implications for lead behaviour in monazite, Geochimica et Cosmochimica Acta, 62, 2475- 2497.

Cocherie, A., Albarède, F., 2001. An improved U-Th-Pb age calculation for electron micropobe dating of monazite, Geochimica et Cosmochimica Acta, 65, 4509 - 4522.

Cocherie, A., Be Mezème, E., Legendre, O., Fanning, C.M., Faure, M., Rossi, P., 2005. Electronmicroprobe dating as a tool for determining the closure of Th- $\mathrm{U}-\mathrm{Pb}$ systems in migmatitic monazites, American Mineralogist, 90, 607- 618.

Cocherie, A., Legendre, O., 2007. Potential minerals for determining U-Th- $\mathrm{Pb}$ chemical age using electron microprobe, Lithos, 93, 288-309, doi:10.1016/j.lithos.2006.03.069.

Duguet, M., Le Breton, N., Faure, M., 2007. P-T paths reconstruction of a collisional event: the example of the Thiviers-Payzac Unit in the Variscan French Massif Central, Lithos, 98, 210-232.

D’Lemos, R.S, Brown, M., Strachan, R.A., 1992, Granite magma generation, ascent and emplacement within a transpressional orogen, Journal of geological Society, London, 149, 487- 490.

Ellwood, B.B., Wenner, D.B., 1981. Correlation of magnetic susceptibility with 18O:16O data in orogenic granites of southern Appalachian Piedmont, Earth Planetary Science Letters, 59, 200-202.

Faure, M. , Pons, J., 1991. Crustal thinning recorded by the shape of the NamurianWestaphalian leucogranite in the Variscan belt of the northwest Massif central, France, Geology, 19, 730-733. 
Faure, M., Pons, J.,Babinault, J.F., 1992. Le pluton du Pont-de-Montvert: un granite syntectonique extravasé vers l'Est pendant le désépaississement crustal varisque du Massif Central français. Comptes Rendus de l'Académie des Sciences, 315, 201-208.

Faure, M., Becq-Giraudon, J-F., 1993. Sur la succession des épisodes extensifs au cours du désépaississement carbonifère du Massif Central français, Comptes Rendus de l’Académie des Sciences Paris, 316, II, 967-973.

Faure, M., 1995. Late Carboniferous extension in the Variscan French Massif central, Tectonics, 14, 132-153.

Faure, M., Charonnat, X., Chauvet, A., Chen, Y., Talbot, J. Y., Martelet, G., Courrioux, G., Monié, P., Milési, J. P., 2001. Tectonic evolution of the Cévennes paraautochthonous domain of the Hercynian French Massif Central and its bearing on ore deposits formation, Bulletin de la Société Géologique de France, 172, 687- 696.

Faure, M., Mézème, E. Be, Duguet, M., Cartier, C., Talbot, J.-Y., 2005. Paleozoic tectonic evolution of medio-europa from the example of the French Massif central and Massif Armoricain, Journal of the virtual Explorer, ISSN 1441-8142, 19, 5, 26 p.

Feybesse, J.L., 1981. Tectonique et microtectonique de la région de Laroquebrou (Cantal, Massif central français). Rôle de la déformation ductile et évolution du Sillon Houiller, Ph-D Thesis, Clermont Ferrand University, France, 250 p.

Finger, F., Broska, I., Roberts, M.P., Schermaier, A., 1998. Replacement of primary monazite by apatite-allanite-epidote coronas in amphibolite faciès gneiss from the eastern Alps, American Mineralogist, 83, 248-258.

Franke, W., 2000. The mid-European segment of the Variscides : tectonostratigraphic units, terrane boundaries and plate tectonic evolution, in Orogenic 
Processes : Quantification and Modelling in the Variscan Belt, edited by Franke, W., Haak, V., Oncken, O., Tanner, D., Special Publications, 179, Geological Society of London, 35-61.

Gébelin, A., Martelet, G., Brunel, M., Faure, M., Rossi, P., 2004. Late Hercynian leucogranites modeling as deduced from new gravity data: the example of the Millevaches massif, Massif Central, France, Bulletin de la Société Géologique de France, 175, 3, 239-248.

Gébelin, A., Martelet, G., Chen, Y., Brunel, M., Faure, M., 2006. Structure of late Variscan Millevaches leucogranite massif in the French Massif Central: AMS and gravity modelling results, Journal of Structural Geology, 28, 148-169.

Gébelin, A., Brunel, M., Monié, P., Faure, M., Arnaud, N., 2007. Transpressional tectonics and Carboniferous magmatism in the Limousin, Massif Central, France: Structural and 40Ar/39Ar investigations, Tectonics, 26, doi:10.1029/2005tc001822.

Gélard, J.P., Castaing, C., Bonijoly, D., Grolier, J., 1986. Structure et dynamique des bassins houillers limniques du massif central, Mémoire de la Société Géologique France, N.S., 149.

Gleizes, G., Leblanc, D., Bouchez, J.-L., 1997. Variscan granites of the Pyrenees revisited: their role as syntectonic markers of the orogen, Terra Nova, 9, 38-41.

Grolier, J., Letourneur, J., 1968. L'évolution tectonique du grand Sillon Houiller du Massif Central francais, XXIII International Geological Congress, 1, 107-116.

Guillen, A., Delos, V., Ledru, P., 2000. A new method to determine lithology and geometry in depth: 3D litho-inversion of potential fields, European Geophysical Society, 
25th General Assembly, Katlenburg- Lindau, Federal Republic of Germany (DEU). Abstract.

Guillen, A., Courrioux, G., Calcagno, P., Lane, R., Lees, T., McInerney, P., 2004. Constrained gravity inversion applied to Broken Hill, extended abstract in: Australian society of exploration geophysicists 17th geophysical conference and exhibition, 1519/08/2004, Sydney, Australia.

Guillen, A., Joly, A., Calcagno, P., Courrioux, G., Fitzgerald, D., McInerney, P., Seikel, R., 2006. Coupling 3D Modelling and Forward-Inverse modelling of potential field data (gravity and magnetic data and tensor components), IAMG06, session 12, Liege (Belgium).

Guillen Antonio, Calcagno Philippe, Courrioux Gabriel, Joly Aurore, Ledru Patrick, 2008. 3D realistic modelling of geology from field data and geological knowledge, Part II - Modelling validation using of gravity and magnetic data inversion, Physics of the Earth and Planetary Interiors, accepted.

Hrouda, F., 1982. Magnetic anisotropy of rocks and its application in geology and geophysics, Geophysical Surveys, 5, 37-82.

Hutton, D.H.W., 1982. A tectonic model for the emplacement of the Main Donegal granite, NW Ireland, Journal of the Geological Society, London, 139, 615-631.

Hutton, D.H.W., 1988, Granite emplacement mechanisms and tectonic controls: Inferences from deformation studies, Royal Society of Edinburgh Transactions, 79, 452455. 
Jackson M, Tauxe L., 1991, Anisotropy of magnetic susceptibility and remanence: developments in the characterization of tectonic, sedimentary, and igneous fabric, Rev Geophys, 29,371-376.

Jelinek, V., 1978, Statistical processing of anisotropy of magnetic susceptibility measured on groups of specimens, Studia geoph. et geodetica., 22, 50-62.

Jelinek, V., 1981, Characterization of the magnetic fabric of rocks, Tectonophysics, 79, 563-567.

Joly, A., Chen, Y., Faure, M., Martelet, G., 2007. A multidisciplinary study of a syntectonic pluton close to a major lithospheric-scale fault: relationships between the Montmarault granitic massif and the Sillon Houiller Fault in the Variscan French Massif Central. Part I: Geochronology, mineral fabrics and tectonic implications, JGR Solid Earth, 112, B10104.

Joly, A., Martelet, G., Chen, Y., Faure, M., 2008. A multidisciplinary study of a syntectonic pluton close to a major lithospheric-scale fault: relationships between the Montmarault granitic massif and the Sillon Houiller Fault in the Variscan French Massif Central. Gravity, aeromagnetic investigations and 3D geologic and geophysical modeling, JGR Solid Earth, 113, B01404.

Lajaunie, C., Courrioux, G., Manuel, L., 1997. Foliation fields and 3D cartography in geology: principles of a method based on potential interpolation, Mathematical Geology, 29, $571-584$.

Lardeaux, J.-M., Ledru, P., Daniel, I., Duchene, S., 2001. The Variscan French Massif Central: a new addition to the ultra-high pressure metamorphic club: exhumation processes and geodynamic consequences, Tectonophysics, 332, 143-167. 
Ledru, P., Lardeaux, J.M., Santallier, D., Autran, A., Quenardel, J.M., Floc'h, J.P., Lerouge, G., Maillet, N., Marchand, J., Ploquin, A., 1989. Où sont les nappes dans le Massif Central français ? Bulletin de la Société Géologique de France, 8, 605-618.

Ledru, P., Courrioux, G., Dallain, C., Lardeaux, J. M., Montel, J. M., Vanderhaeghe, O., Vitel G., 2001. The Velay dome (French Massif Central): melt generation and granite emplacement during orogenic evolution, Tectonophysics, 342, 3-4, 207-237.

Letourneur, J., 1953. Le grand Sillon Houiller du plateau central français, Bulletin Carte géologique de la France, 238, LI, 235pp.

Li, Y., Oldenburg, D., 1998. 3D inversion of gravity data, Geophysics, 63, 109-119.

Ludwig, K.R., 1999. Users manual for ISOPLOT/EX, version 2. A geochronological toolkit for Microsoft Excel, Berkeley Geochronology Center, Special Publication 1a.

Malavielle, J., Guihot, S., Costa, S., Lardeaux, J.-M., Gardien, V., 1990. Collapse of thickened Variscan crust in the French Massif Central : Mont Pilat extensional shear zone and St Etienne carboniferous basin, Tectonophysics, 177, 139-149.

McCaffrey, K.J.W., 1992. Igneous emplacement in a transpressive shear zone: Ox Mountains igneous complex, J. Geol. Soc. London, 149, 221-235.

McNulty, B.A., Tobisch, O.T., Cruden, A.R., Gilder, S., 2000. Multistage emplacement of the Mount Givens pluton, central Sierra Nevada Batholith, California, Geol. Soc. Am. Bull., 112, 119-135, doi: 10.1130/0016-7606.

Malavieille, J., 1993. Late orogenic extension in mountain belts: insight from the Basin and Range and the late Paleozoic Variscan Belt, Tectonics, 12, 1115-1130.

Martelet, G., 1999. Modélisation de la structure crustale et du comportement mécanique de la lithosphère à partir des anomalies gravimétriques. Applications à 
l'Himalaya et au massif granitique du Mont Lozère, Cévennes, $P h-D$ thesis, Institut de Physique du Globe de Paris, 324p.

Martelet, G., Debeglia, N., Truffert, C., 2002. Homogénéisation et validation des corrections de terrain gravimétriques jusqu'à la distance de 167 km sur l'ensemble de la France, Comptes Rendus de l'Académie des Sciences, 334, 449-454.

Martelet, G., Calcagno, P., Gumiaux, C., Truffert, C., Bitri, A., Gapais, D., Brun, J. P., 2004. Integrated 3D geophysical and geological modelling of the Hercynian Suture Zone in the Champtoceaux area (south Brittany, France), Tectonophysics, 382, 1-2, 117 128.

Matte, P., 1986. La chaîne varisque parmi les chaînes paléozoïques péri atlantiques, modèle d'évolution et position des grands blocs continentaux au Permo -Carbonifère, Bulletin de la Société Géologique de France, 8, 9 - 24.

Menichetti, V., Guillen, A., 1983. Simultaneous interactive magnetic and gravity inversion, Geophysisical Prospection, 31, 929-944.

Monié P., Bouchot, V., Faure, M., Charonnat, X., Najou, K., 1999. 40Ar/39Ar laserprobe dating of $\mathrm{W}-\mathrm{Au}-\mathrm{Sb}$ deposits in the southern French Massif Central (Cévennes, Châtaigneraie), EUG 10, Strasbourg, 477.

Montel, J-M., Foret, S., Veschambre, M., Nicollet, C., Provost, A., 1996. Electron microprobe dating of monazite, Chemical Geology, 131, 37 - 53.

Montel, J.-M., Kornprobst, J., Vielzeuf, D., 2000. Preservation of old U-Th-Pb ages in shielded monazite: example from Beni Bousera Hercynian Kinzigites (Morroco), Journal of Metamorphic Geology, 18, 335- 342. 
Mosegaard, K., Tarantola A., 1995. Monte Carlo sampling of solutions to inverse problems, Journal of Geophysical Research, 100, No. B7, 124321-12447.

Najoui, K., Leyreloup, A., Monié, P., 2000. Condition et âge de mise en place des granitoïdes de la zone externe sud du massif central Français: étude pétro-structurale et géochronologique des roches de leurs auréoles de contact. Implications géotectoniques. Bull. Soc. Géol. France, 171, 495- 510.

Neves, S., Vauchez, A., 1995, Magmas emplacement and shear zone nucleation and development in northeast Brazil (Fazenda Nova and Pernambuco shear zones; state of Pernambuco), Journal of South American Earth Sciences, 8, 289-298.

Olivier, P., Ameglio, L., 2002. Structure et mise en place en régime décrochant puis rotation tardi-magmatique des plutons granitiques hercyniens du Veinazés et de Marcolés (Châtaigneraie, Massif central français), Bulletin de la Société Géologique de France, 173, 207-218.

Passchier, C.W., Trouw, R.A.J., 1996. Microtectonics, Springer, Berlin 298pp.

Parrish, R. R.,1990. U - Pb dating of monazite and its application to geological problems, Canadian Journal of Earth Sciences, 27, 1431 - 1450.

Paris, F., Robardet M., 1990. Early Palaeozoic palaeobiogeography of the Variscan regions, Tectonophysics, 177, 1-3, 193-213.

Paterson, S.R., Vernon, R.H., Tobisch, O.T., 1989. A review of criteria for the identification of magmatic and tectonic foliations in granitoids, Journal of Structural Geology, 11, 349-363.

Paterson, S.R., Schmidt, K.L., 1999, Is there a spatial relationship between faults and plutons? Journal of Structural Geology, 21, 1131-1142. 
Pignotta, G.S., Benn, K., 1999. Magnetic fabrics of the Barrington Passage pluton, Meguma Terrane, Nova Scotia: a two-stage fabric history of syntectonic emplacement. Tectonophysics, 307, 75-92.

Pommier, A., Cocherie, A., Legendre, O., 2002. EPMA Dating User's Manual: Age Calculation from Electron Probe Microanalyser Measurements of $\mathrm{U}-\mathrm{Th}-\mathrm{Pb}, B R G M$ Documents, 9 pp.

Rochette, P., Jackson, M., Aubourg, C., 1992. Rock magnetism and the interpretation of anisotropy of magnetic susceptibility, Reviews of Geophysics, 30, 209-226.

Rochette, P., Aubourg, C., Perrin, M., 1999. Is this magnetic fabric normal? A review and case studies in volcanic formations, Tectonophysics, 30, 1-2, 219-234.

Suzuki, K., Adachi M., 1991. The chemical Th - U - total Pb isochron ages of zircon and monazite from the gray granite of the Hida terrane, Japan, Journal of Earth Science, Nagoya Univ, 38, $11-37$.

Talbot, J.Y., Martelet, G., Courrioux, G., Chen, Y., Faure, M., 2004. Emplacement in an extensional setting of the Mont Lozère-Borne granitic complex (SE France) inferred from comprehensive AMS, structural and gravity studies, Journal of Structural Geology, 26, 1, 11-28.

Talbot, J.-Y., Chen, Y., Faure, M., 2005a. A magnetic fabric study of the AigoualSaint Guiral-Liron granite pluton (French Massif Central) and relationships with its associated dikes, Journal of Geophysical Research, 110, B12106, doi:10.1029/2005JB003699. 
Talbot, J.Y., Faure, M., Chen, Y., Martelet, G., 2005b. Pull-apart emplacement of the Margeride granitic complex (French Massif Central), Implications for the late evolution of the Variscan orogen, Journal of Structural Geology, 27, 9, 1610-1629.

Tarantola, A., Valette, B., 1982. Inverse Problems = Quest for Information. J. Geophys., 50, $159-170$.

Tarling D.H., Hrouda F., 1993, The magnetic anisotropy of rocks. Chapman and Hall, London, pp 1-217.

Tikoff, B., Teyssier, C., 1992, Crustal-scale, en echelon "P-shear" tensional bridges; a possible solution to the batholithic room problem, Geology, 20, 927-930, doi: 10.1130/0091-7613(1992)020<0927: CSEEPS >2.3.CO;2.

Tikoff, B., Saint Blanquat, M., 1997, Transpressional shearing and strike-slip partitioning in the Late Cretaceous Sierra Nevada magmatic arc, California, Tectonics, 16, 442-459, doi: 10.1029/97TC00720.

Torge, W., 2001, Geodesy, 3rd edition, de Gruyter, 416 p., ISBN 3110170728 , 9783110170726.

Van den Driessche, J., Brun, J.P., 1989. Un modèle de l'extension paléozoïque supérieur dans le sud du Massif central, Comptes Rendus de l'Académie des Sciences, Série 2, 309, 1607-1613.

Vanderhaege, O., Teyssier, C., 2001. Partial melting and flow of orogen, Tectonophysics, 342, 451-472.

Vernon, R.H., 2000. Review of microstructural evidence of magmatic and solid-state flow, Electronic Geosciences, 5, 2. 
Vigneresse, J.-L., Brun, J.-P., 1983. Les leucogranites armoricains marqueurs de la déformation régionale : apport de la gravimétrie, Bulletin de la Société Géologique de France, t.XXV-3, 357-366.

Vigneresse, J.L., 1990. Use and misuse of geophysical data to determine the shape at depth of granitic intrusions, Geological Journal, 25, 249-260.

Vigneresse, J.L., Bouchez, J.L., 1997. Successive granitic magma batches during pluton emplacement: the case of Cabeza de Araya (Spain), Journal of Petrology, 38, $1767-1776$.

Vivier, G., 1970. Etude pétrographique et géochronologique de la Châtaigneraie (Massif Central Français), Ph-D Thesis, Clermond-Ferrand University, France.

Vivier, G., Lasseyre, M., 1973. Age hercynien des granites de la châtaigneraie (SW du Massif Central Français), Bulletin de la Société Géologique de France, 7, XV, 3-4, 283-287.

Wendt, I., Carl C., 1991. The statistical distribution of the mean squared weighted deviation, Chemical Geology (Isotope Geoscience Section), 86, 275-285.

Williams, M.L., Scheltema, K.E., Jercinovic, M.J., 2001. Highresolution compositional mapping of matrix phases: implications for mass transfer during crenulation cleavage development in the Moretown Formation, western Massachusetts, Journal of Structural Geology, 23, 923-939.

William, M.L., Jercinovic, M.J., 2002. Microprobe monazite geochronology: putting absolute time into microstructural analysis, Journal of Structural Geology, 86, 10131028. 
Zapletal, K., 1990. Low field susceptibility anisotropy of some biotite crystals, Physics Earth Planetary Interiors, 63, 85-97.

Figures and tables

Figure 1. Structural map of the Glénat, Omps and Boisset plutons (a), located in the French Massif Central (b).

Figure 2. Characteristic textures of rocks observed in the Glénat, Omps and Boisset massifs. Thin sections are perpendicular to the magnetic foliation and parallel to the magnetic lineation defined by AMS study. (a) Schlieren layering in the medium grain facies of the Glénat pluton. (b) Oriented accumulation of potassic feldspar megacrysts belonging to the porphyritic facies of the Omps pluton. (c) Boisset pluton strongly deformed in the solid state. The S-C surfaces, parallel to the lineation indicate a top-tothe SSW shearing. (d) Slickenlines with a pitch of $40^{\circ} \mathrm{S}$ in a $\mathrm{N}^{\circ} 165$ vertical granitic fault plane show sinistral movements. (e) and (f) Magmatic textures, e: large and undeformed biotite $(\mathrm{Bi})$ and quartz $(\mathrm{Qz})$ grains coexist with $\mathrm{K}$-feldspar $(\mathrm{FK})$ indicating primary formation; f: Compositional zoning of a plagioclase. (g) Microstructure with weak solidstate deformation: Quartz grains are weakly recrystallized with a slight neograin formation, biotite is bent. (h) Intense solid state fabric in Boisset granite mylonite showing ribbon of recrystallized quartz grain and sheared biotite.

Figure 3. Optical photomicrographs showing contact aureole of the Glénat, Omps and Boisset massifs and their associated defomations. (a) Quartz and muscovite 
asymmetric pressure shadows around garnet porphyroblast showing top-to-the southeast shearing recrystallization tails (contact aureole of Glénat pluton: 4446’47.2”N, $\left.2^{\circ} 12^{\prime} 30.5^{\prime \prime} \mathrm{E}\right)$. (b) Sigmoidal iron oxide in the contact aureole of Boisset pluton; $44^{\circ} 44^{\prime} 13.7^{\prime}$ N, $2^{\circ} 14^{\prime} 10.2^{\prime \prime}$ E. (c) Southeastward post-folial shear bands and K-felspar sigmoidal (contact aureole of Boisset pluton: 4444’33.8”N, $\left.2^{\circ} 14^{\prime} 37.0^{\prime \prime} \mathrm{E}\right)$. (d) Intense recrystallised quartz grains with grain size reduction with top-to-the SE shearing (contact

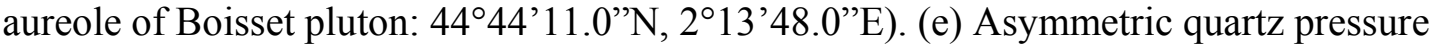
shadows around K-felspar clast showing a top-to-the SE shearing in contact micaschists around Boisset pluton; $44^{\circ} 47^{\prime} 4.5^{\prime \prime} \mathrm{N}, 2^{\circ} 15^{\prime} 7.2^{\prime \prime} \mathrm{E}$. (f) Staurolite crystallized during an early regional metamorphic event and boudinaged during the Boisset pluton emplacement, voids that accommodated the brittle stretching are filled by chlorite contact aureole; 4446’5.4’N, 2¹0'19.1’’E.

Figure 4. Deformation domains within the Glénat, Omps and Boisset plutons.

Figure 5. BSE images of representative monazite grains from the Glénat, Omps and Boisset granites. The upper raw images $(\mathrm{a}, \mathrm{b})$ illustrate the textural relationships of monazite grains with the surrounding minerals. Monazite is included in biotite or along biotite grain boundary. The lack of U-Th zonation in monazite complies with a single stage of crystallization (c, d).

Figure 6. $\mathrm{U} / \mathrm{Pb}$ vs $\mathrm{Th} / \mathrm{Pb}$ - isochron diagrams for monazites from each studied pluton: Glénat, Omps and Boisset.Sample location : 44 $56^{\prime} 24.3^{\prime \prime} \mathrm{N}$ and $2^{\circ} 15^{\prime} 46.9^{\prime \prime} \mathrm{E}$ for the Glénat pluton (G14), at $44^{\circ} 55^{\prime} 27.5^{\prime \prime} \mathrm{N}$ and $2^{\circ} 16^{\prime} 04.5^{\prime}$ 'E for the Omps pluton (O17) and at $44^{\circ} 44^{\prime} 58.4^{\prime \prime} \mathrm{N}$ and $2^{\circ} 15^{\prime} 01.9^{\prime} ' \mathrm{E}$ for the Boisset pluton (B63). 
Figure 7. Hysteresis curves, in field up to 1 Tesla for 3 specimens of each representative studied pluton showing the presence of paramagnetic minerals.

Figure 8. Geographic distribution and frequency histogram of bulk magnetic susceptibility $(\mathrm{Km})$.

Figure 9. Geographic distribution of the shape parameter $\mathrm{T}$ for the three studied plutons

Figure 10. Geographic distribution of the anisotropy degree Pj for the three studied plutons

Figure 11. Plot of anisotropy degree $\mathrm{Pj}$ and shape $\mathrm{T}$ parameters showing oblate dominant AMS ellipsoid (a). Plot of anisotropy degree $\mathrm{Pj}$ and magnetic susceptibility $\mathrm{Km}$ showing no relation between them (b). Grey, dark grey and black symbols correspond respectively to the Glénat, Omps and Boisset plutons.

Figure 12. Equal-area and lower hemisphere projection of the directions of the magnetic susceptibility axes from 27 sites with their geographical corresponding location within the Glénat pluton. The three main axes of ellipsoid (K1, K2 and K3) are represented by square, triangle and circle, respectively, with 95\% confidence zone. Small grey symbols are for the specimen data, the large black symbols are for the average site data.

Figure 13. Equal-area and lower hemisphere projection of the directions of the magnetic susceptibility principal axes from 24 sites with their geographical corresponding location within the Omps and Boisset pluton. The three main axes of ellipsoid (K1, K2 and K3) are represented by square, triangle and circle, respectively, 
with $95 \%$ confidence zone. Small grey symbols are for the specimen data, the large black symbols are for the average site data.

Figure 14. Magnetic foliation pole (K3) and lineation (K1) within the granitic plutons of Glénat, Omps and Boisset. Equal area and lower-hemisphere projection. Ellipses define areas with consistent AMS orientations. (a) Strike and dip of magnetic foliation at individual sites with the stereogram of poles to foliation of each area. (b) Plunge and trend of magnetic lineation at individual sites with the stereogram of lineation orientation of each area.

Figure 15. Residual Bouguer anomaly map of the Glénat, Omps and Boisset plutons with location of previous (black dots) and new (white dots) gravity stations. Major geological limits of the plutons (thin black lines) and faults (thick black lines) are drawn.

Figure 16. Decrease of the root mean squared difference between the 3D model gravity effect and the Bouguer anomaly map, along 5 million iterations. Models with misfit inferior or equal to $1 \mathrm{mGal}$ are retained to derive the final most probable model.

Figure 17. Three most probable density cross-sections derived from gravity inversion after 5 million iterations. Black lines correspond to the preliminary model.

Figure 18. Regional synthesis of the magnetic lineations in the Namurian plutons of the Southern MCF.

Table 1. Data of anisotropy of magnetic susceptibility obtained from this study. n: number of measured specimens; BMS: Bulk Magnetic Susceptibility in 10 $\mu$ SI; Dec, Inc, a95min, a95max: declination, inclination, maximal and minimal 95\% confidence 
intervals from Jelinek (1978) bimodal statistics, respectively, in degree; Pj: corrected anisotropy degree and T: ellipsoid shape parameter (Jelinek, 1981; Hrouda, 1982).

Table 2. Density measurements of geological formations outcropping in the studied area. 


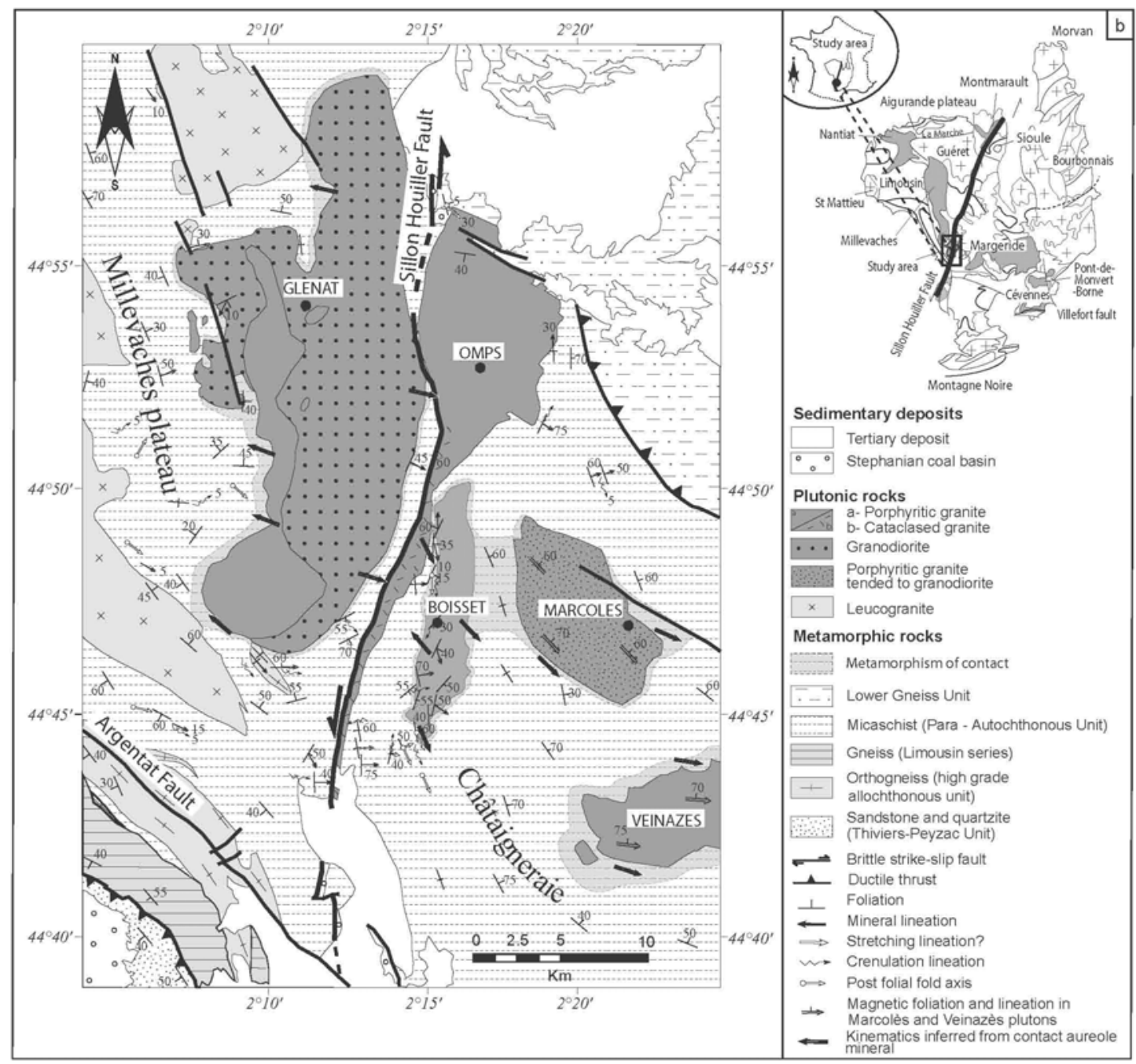



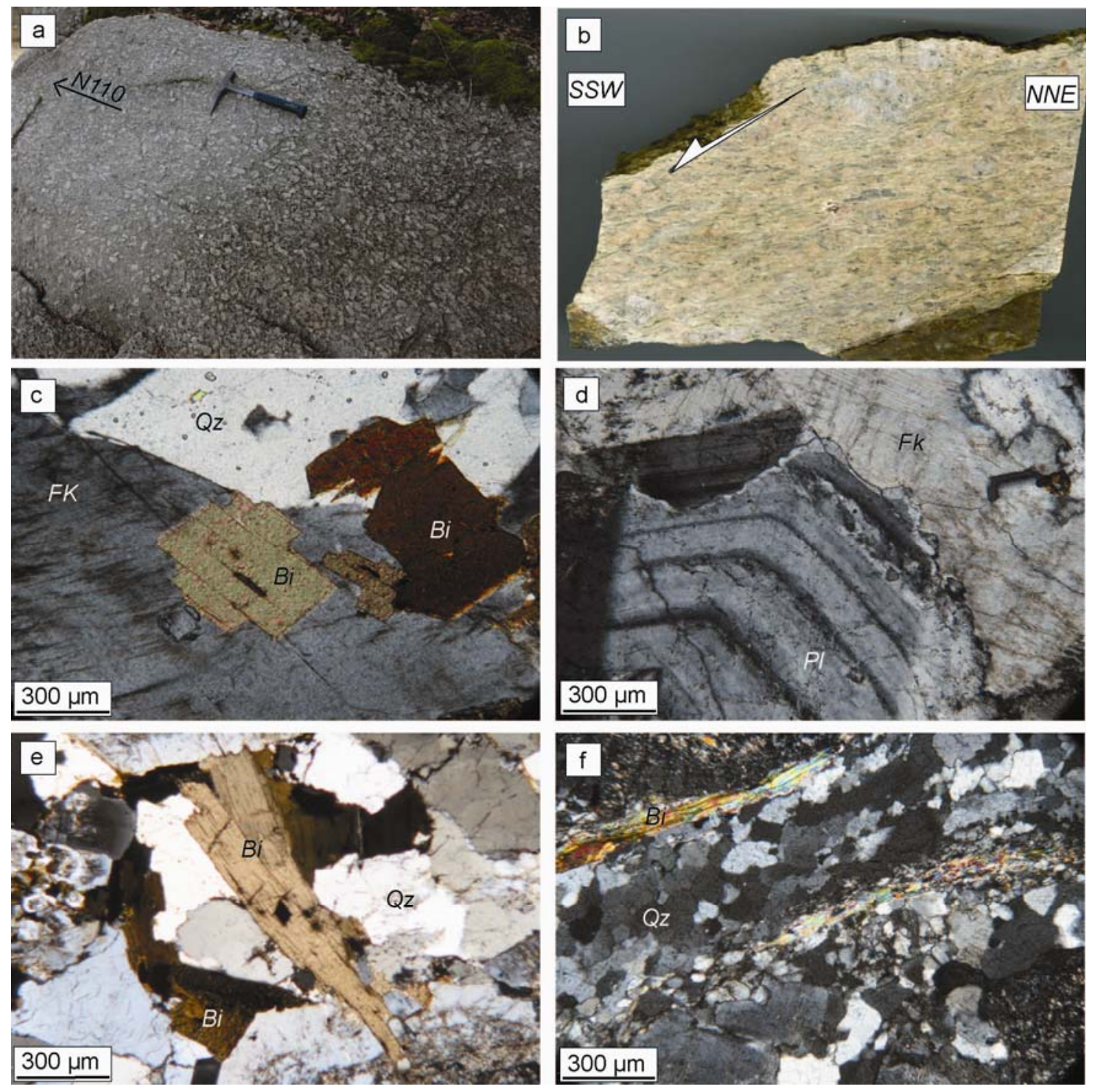

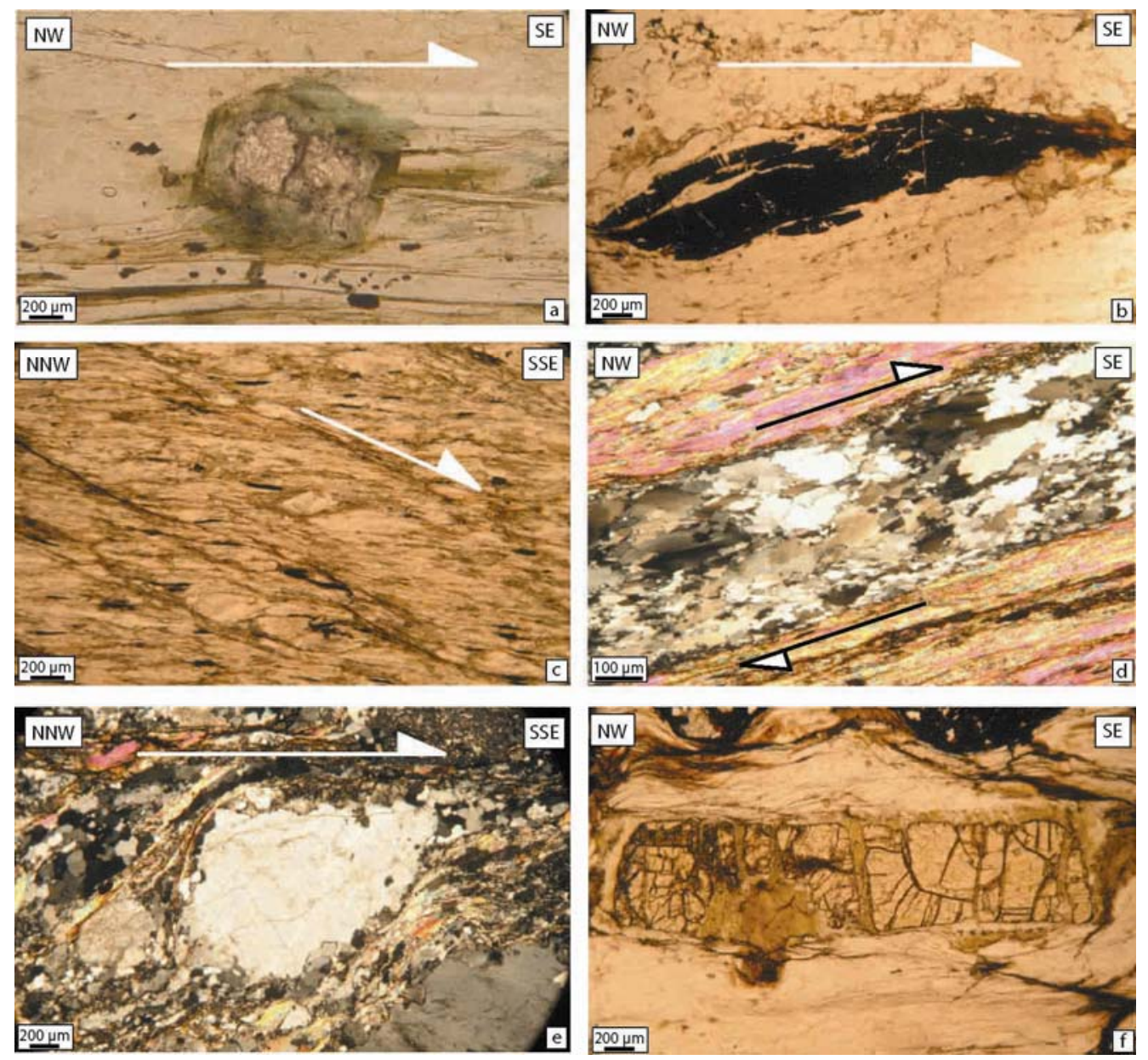


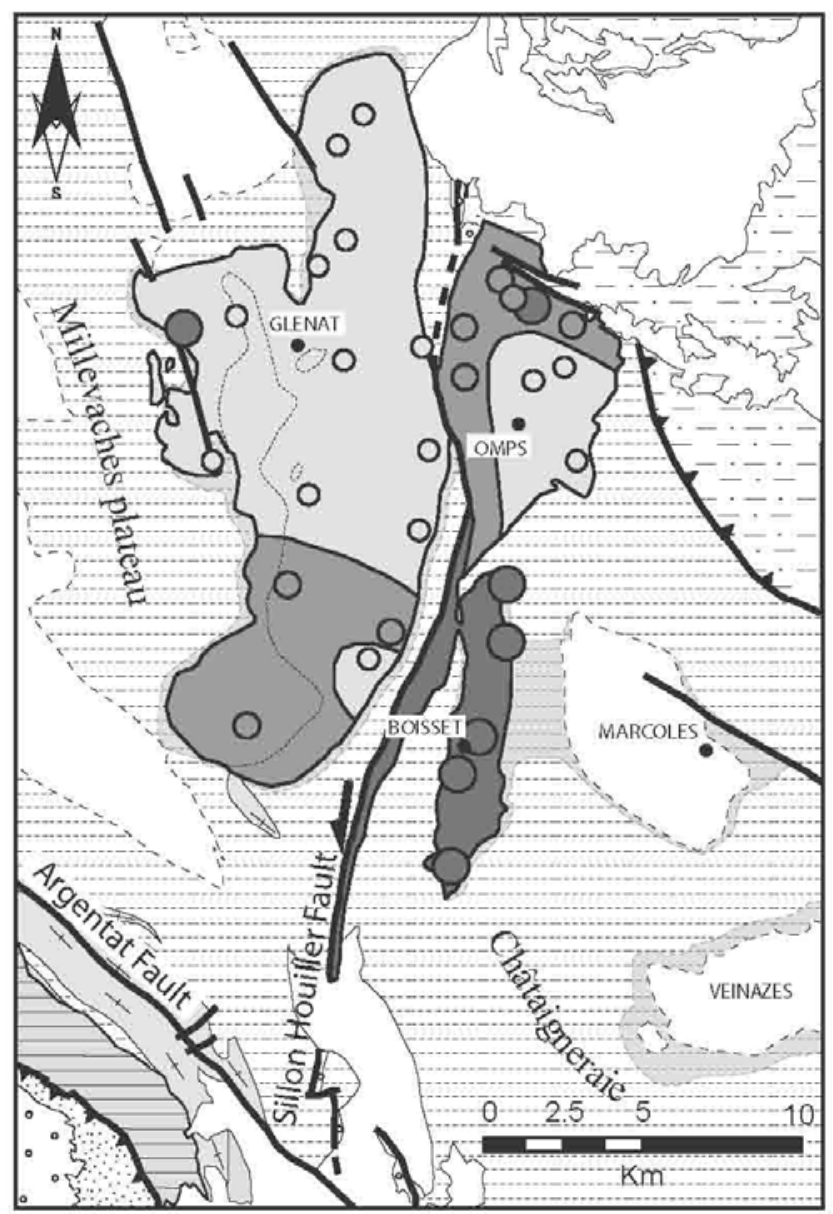

Sedimentary deposits

Tertiary deposit

Stephanian coal basin

Metamorphic and plutonic rocks

Plutonic rocks

Metamorphism of contact

Lower Gneiss Unit

Micaschist (Para - Autochthonous

Unit)

Gneiss (Limousin series)

Orthogneiss (high grade

allochthonous unit)

Sandstone and quartzite

(Thiviers-Peyzac Unit)

$\rightleftharpoons$ Brittle strike-slip fault

_. Ductile thrust

Characterictic type of microstructure of 30 thin sections of Glénat, Omps and Boisset plutons
- Magmatic microstructure
- Weak solid-state fabric Intense solid state fabric

Inverse squared distance weighted interpolation of textures of Glénat, Omps and Boisset plutons Magmatic microstructure Weak solid-state fabric Intense solid state fabric 


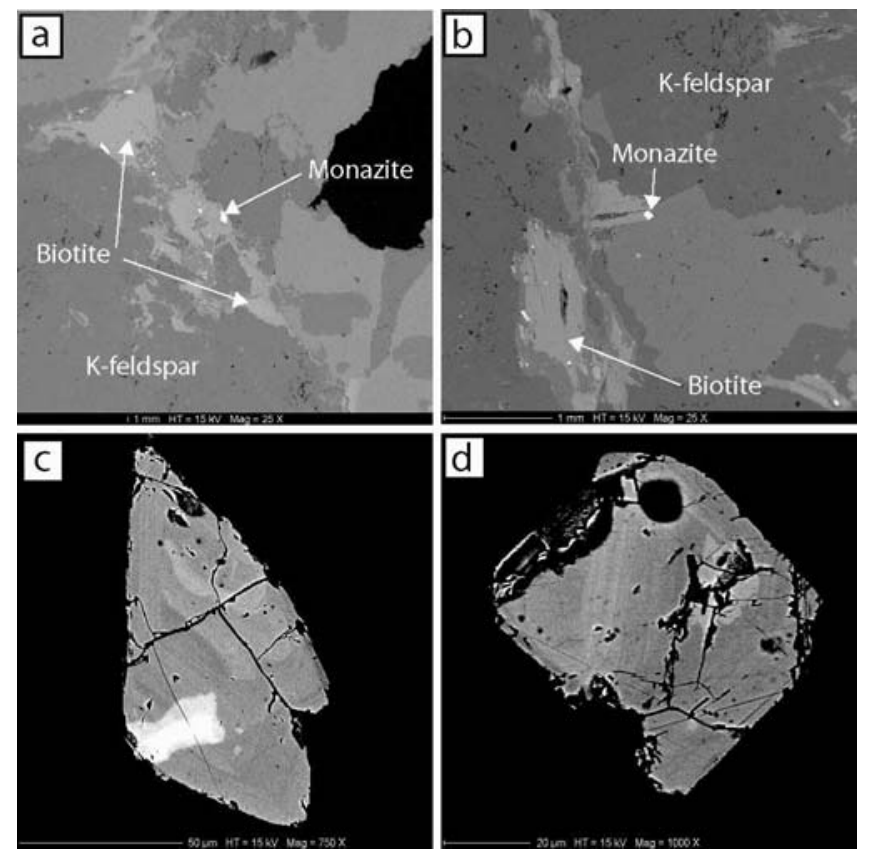




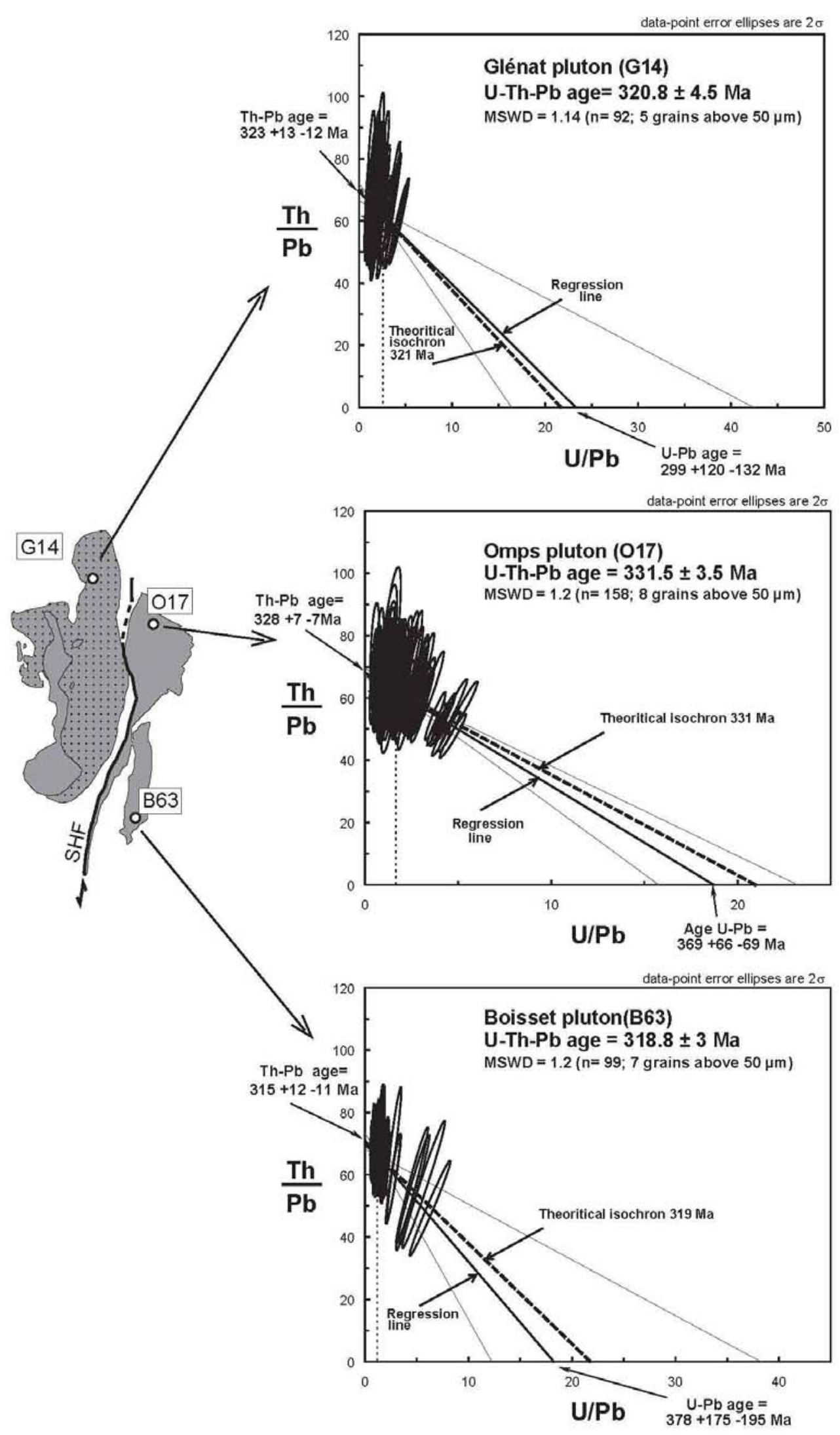




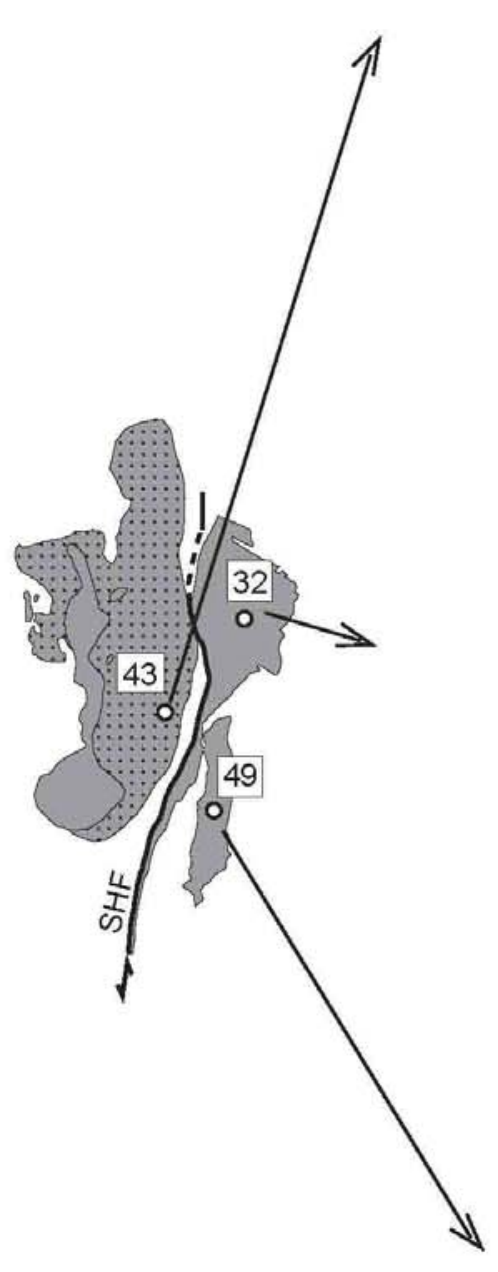

Glénat Pluton (43)
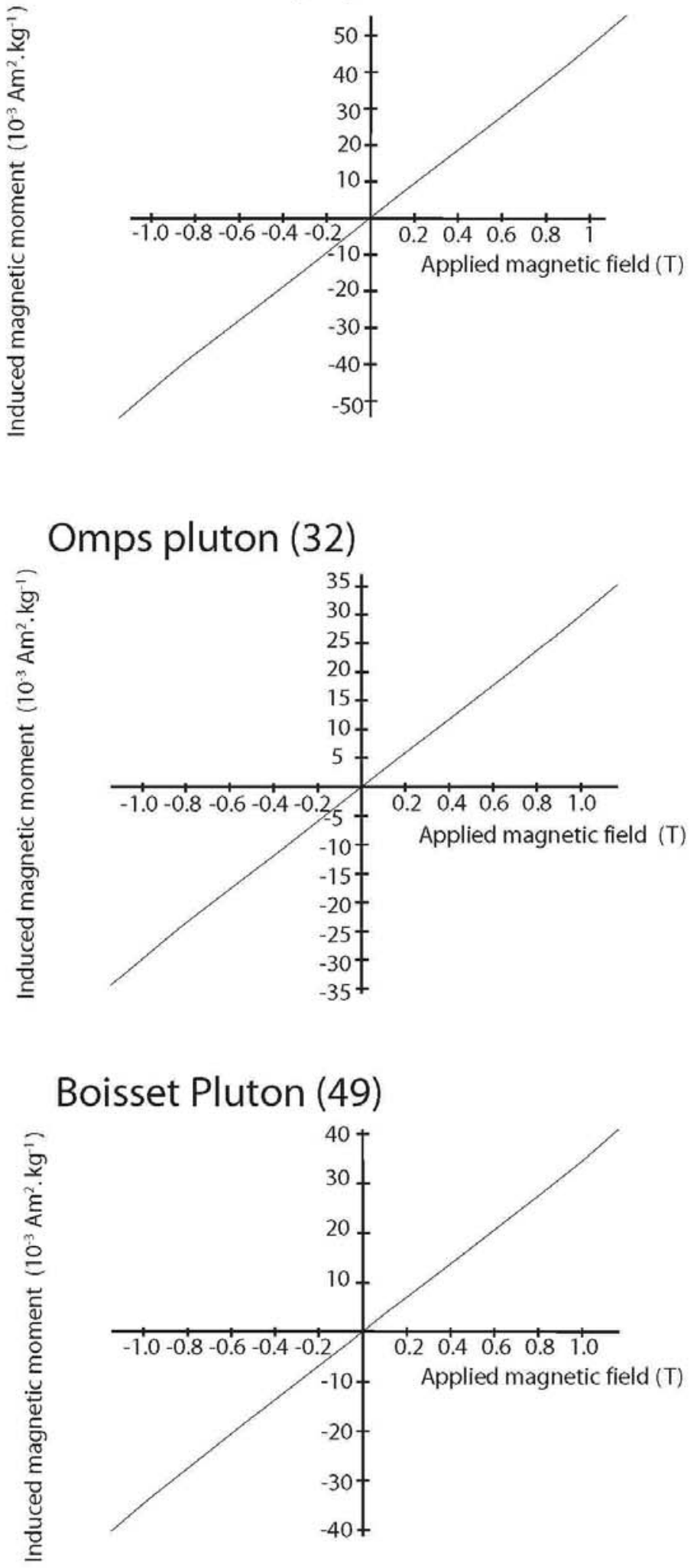


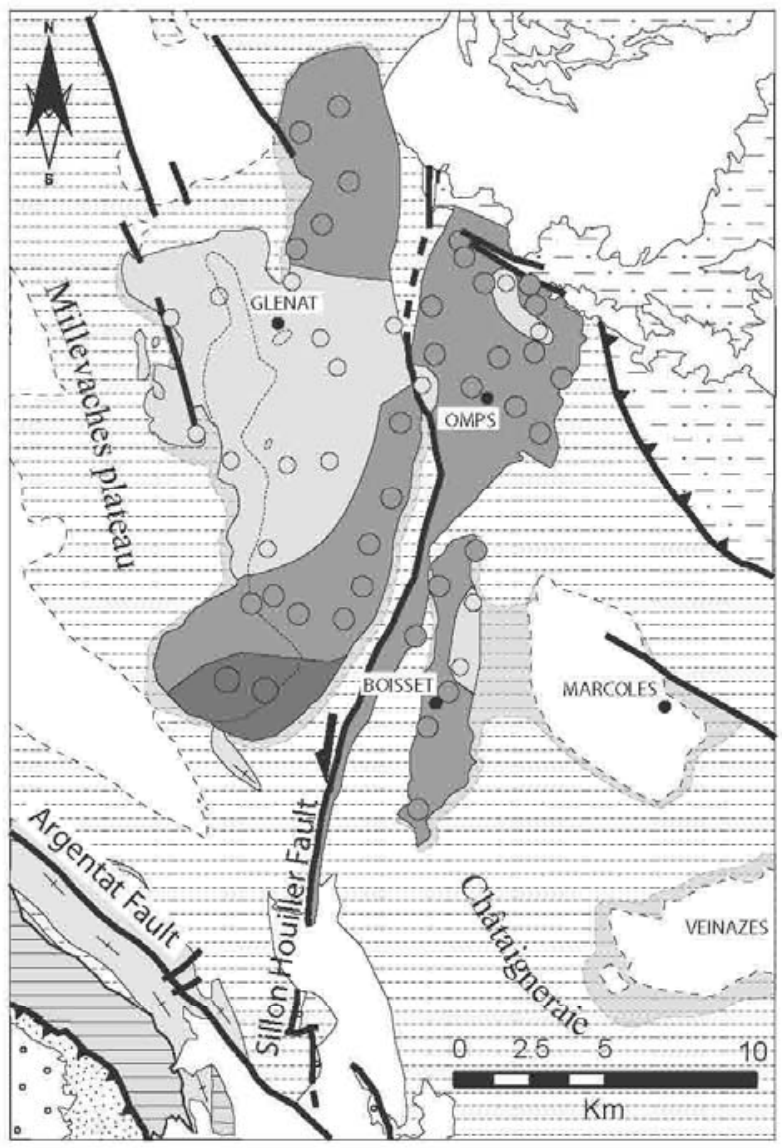

Sedimentary deposits

Tertiary deposit

Stephanian coal basin

Metamorphic and plutonic rocks

Plutonic rocks

Metamorphism of contact

Lower Gneiss Unit

Micaschist (Para - Autochthonous

Unit)

Gneiss (Limousin series)

Orthogneiss(high grade

allochthonous unit)

Sandstone and quartzite

(Thiviers-Peyzac Unit)

$\Longrightarrow$ Brittle strike-slip fault

ـ Ductile thrust

Magnetic susceptibility $\mathrm{Km}$ by site on Glénat, Omps and Boisset plutons

- $\mathrm{Km}<100 \mu \mathrm{SI}$

- $100 \mu S|<K m<150 \mu S|$

- $\mathrm{Km}>150 \mu \mathrm{SI}$

Inverse squared distance

weighted interpolation of $\mathrm{Km}$

on Glénat, Omps and Boisset plutons

$\mathrm{Km}<100 \mu \mathrm{SI}$

$100 \mu \mathrm{S} \mid<\mathrm{Km}<150 \mu \mathrm{SI}$

$\mathrm{Km}>150 \mu \mathrm{SI}$

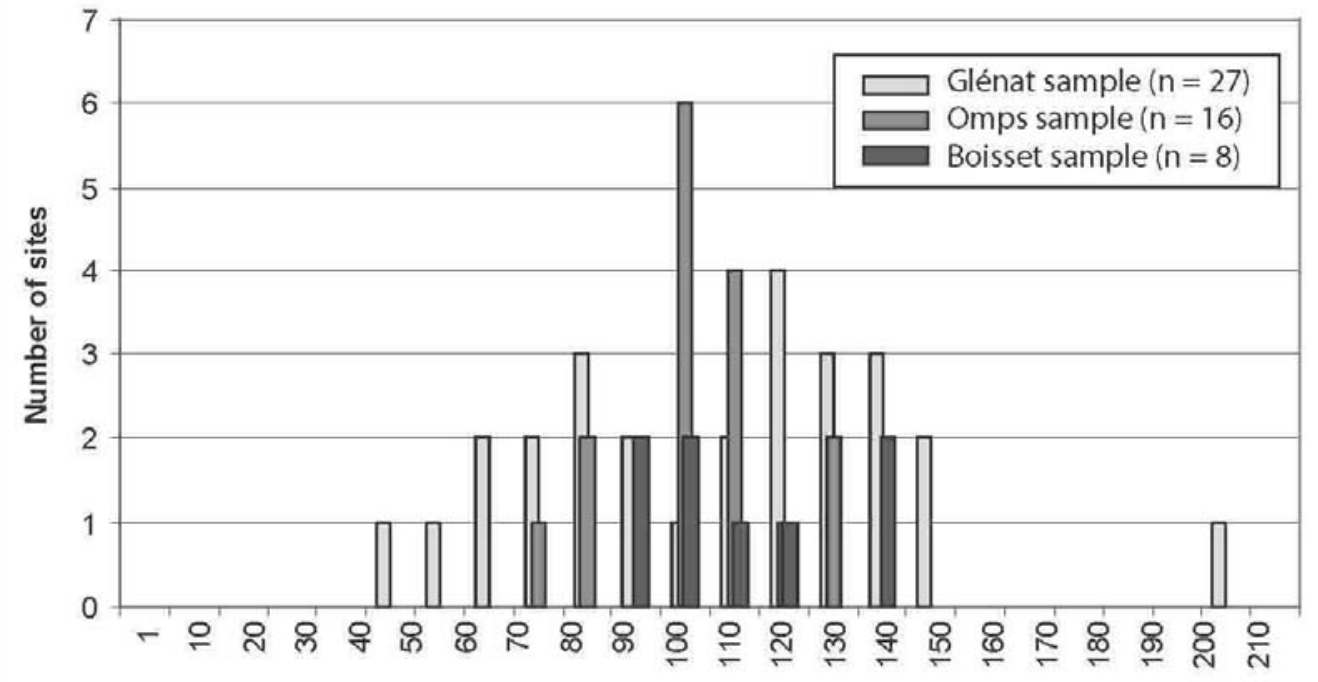

$\mathrm{Km}(\mu \mathrm{SI})$ 


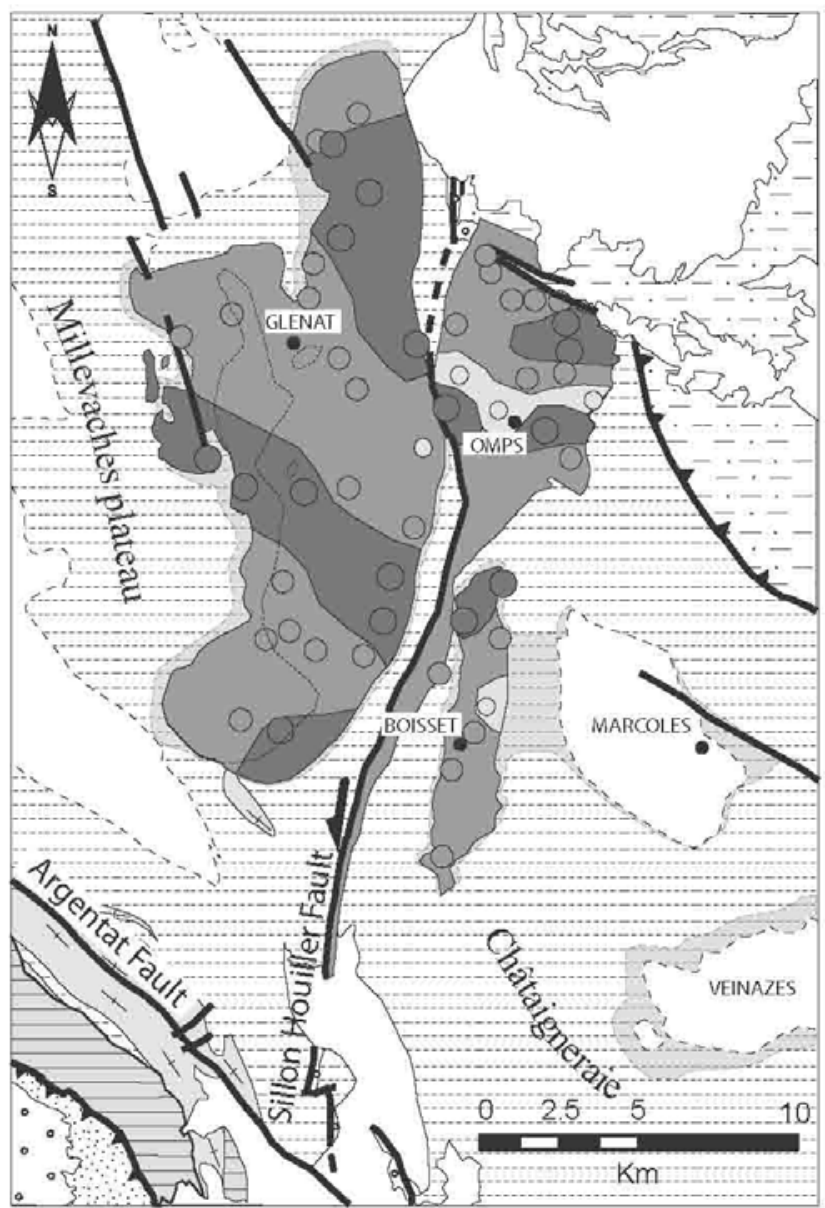

Sedimentary deposits

$\square$ Tertiary deposit

$\because$ Stephanian coal basin

Metamorphic and plutonic rocks

Plutonic rocks

Metamorphism of contact

-_. Lower Gneiss Unit

Micaschist (Para - Autochthonous Unit)

Gneiss (Limousin series)

Orthogneiss

allochthonous unit)

Sandstone and quartzite

(Thiviers-Peyzac Unit)

$\Longrightarrow$ Brittle strike-slip fault

— Ductile thrust

Shape parameter $\mathrm{T}$ by site

on Glénat, Omps and Boisset plutons
- $T<0$
- $0<T<0,5$
$T>0,5$

Inverse squared distance weighted interpolation of $T$

on Glénat, Omps and Boisset plutons

$\square<0$
$0<T<0,5$
$T>0,5$




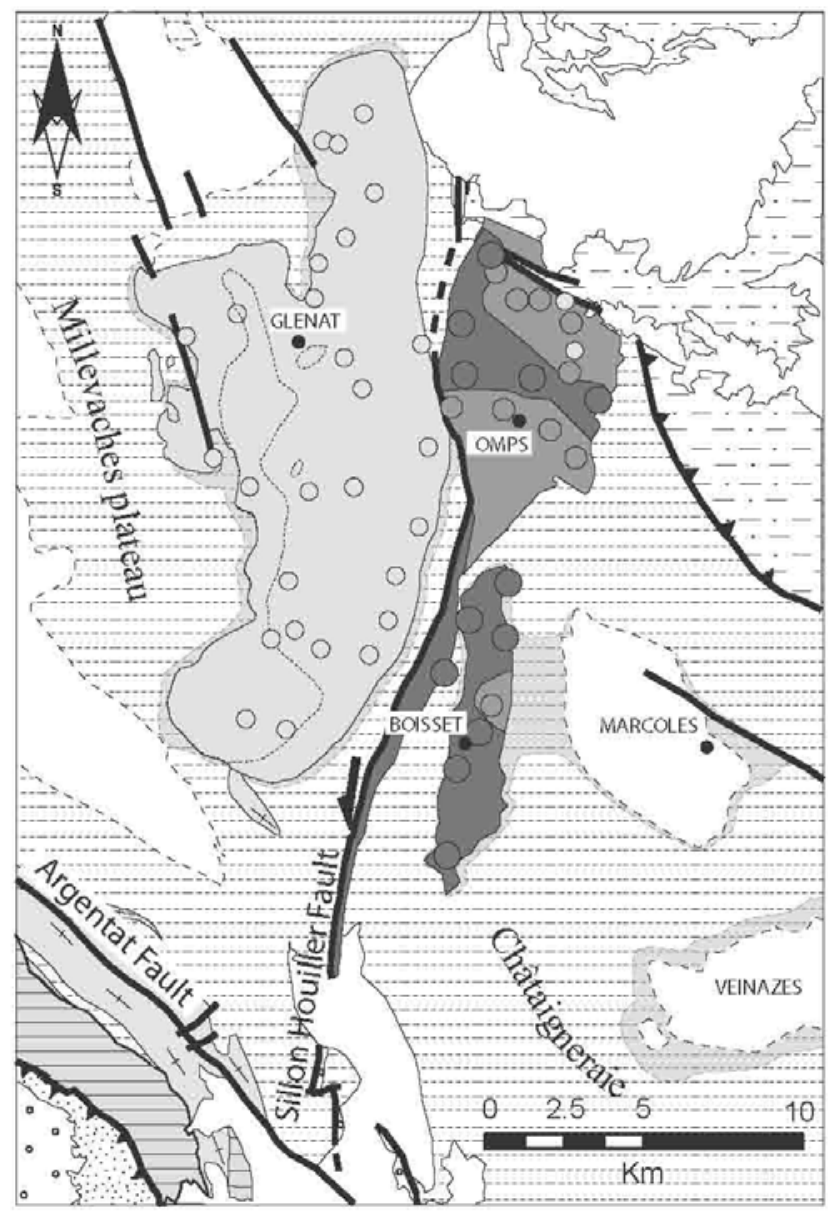

Sedimentary deposits

$\square$ Tertiary deposit

${ }^{\circ} \circ$ Stephanian coal basin

Metamorphic and plutonic rocks

Plutonic rocks

Metamorphism of contact

Lower Gneiss Unit

Micaschist (Para - Autochthonous Unit)

Gneiss (Limousin series)

Orthogneiss

allochthonous unit)

Sandstone and quartzite

(Thiviers-Peyzac Unit)

Brittle strike-slip fault

_. Ductile thrust

Anisotropy degree $\mathrm{Pj}$ by site

on Glénat, Omps and Boisset plutons

() $\mathrm{Pj}<2 \%$

$2<\mathrm{Pj}<5 \%$

P $\mathrm{Pj}>5 \%$

Inverse squared distance

weighted interpolation of $\mathrm{Pj}$

on Glénat, Omps and Boisset plutons

$\square \mathrm{Pj}<2 \%$

$2 \%<P j<5 \%$

$\mathrm{Pj}>5 \%$ 

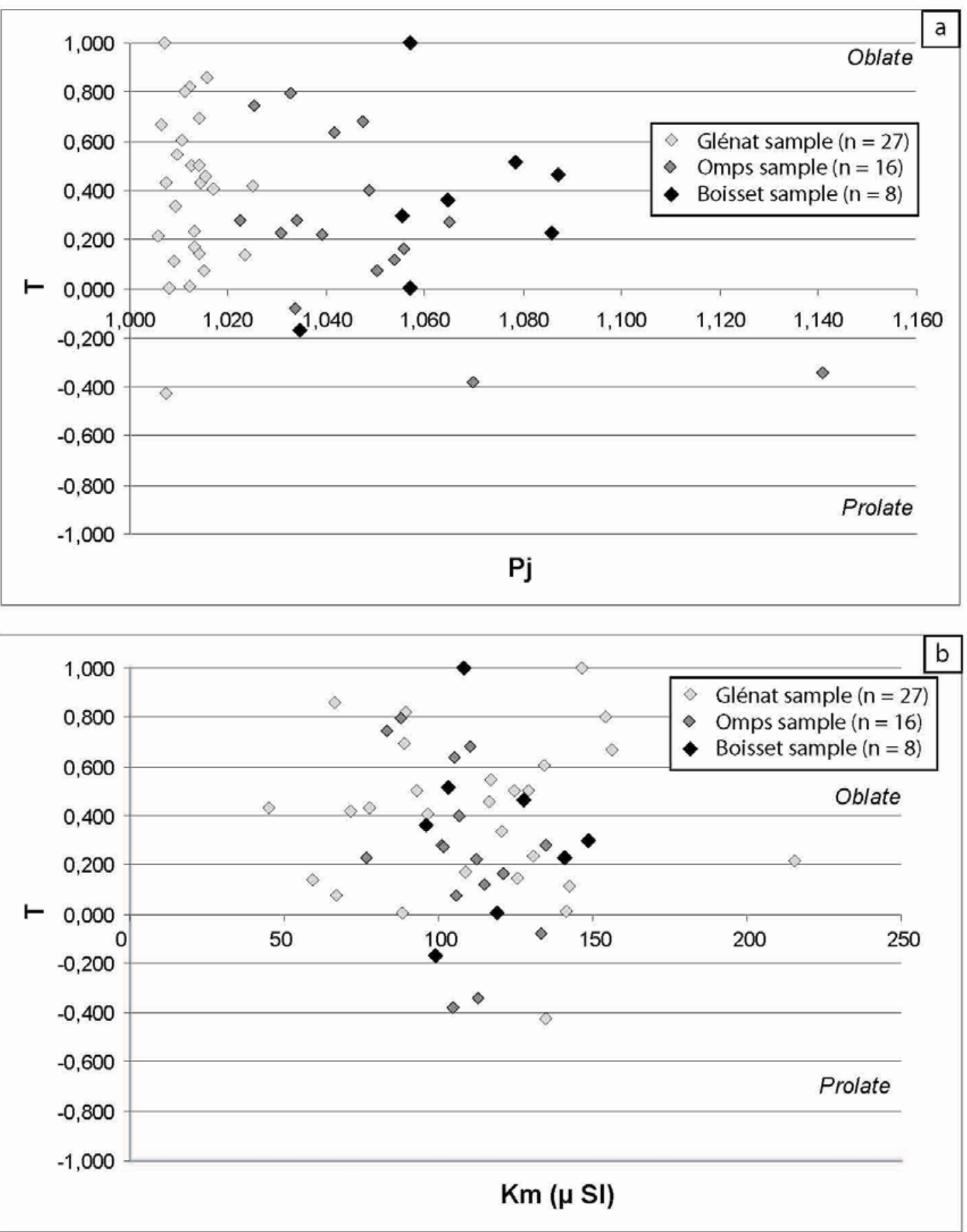


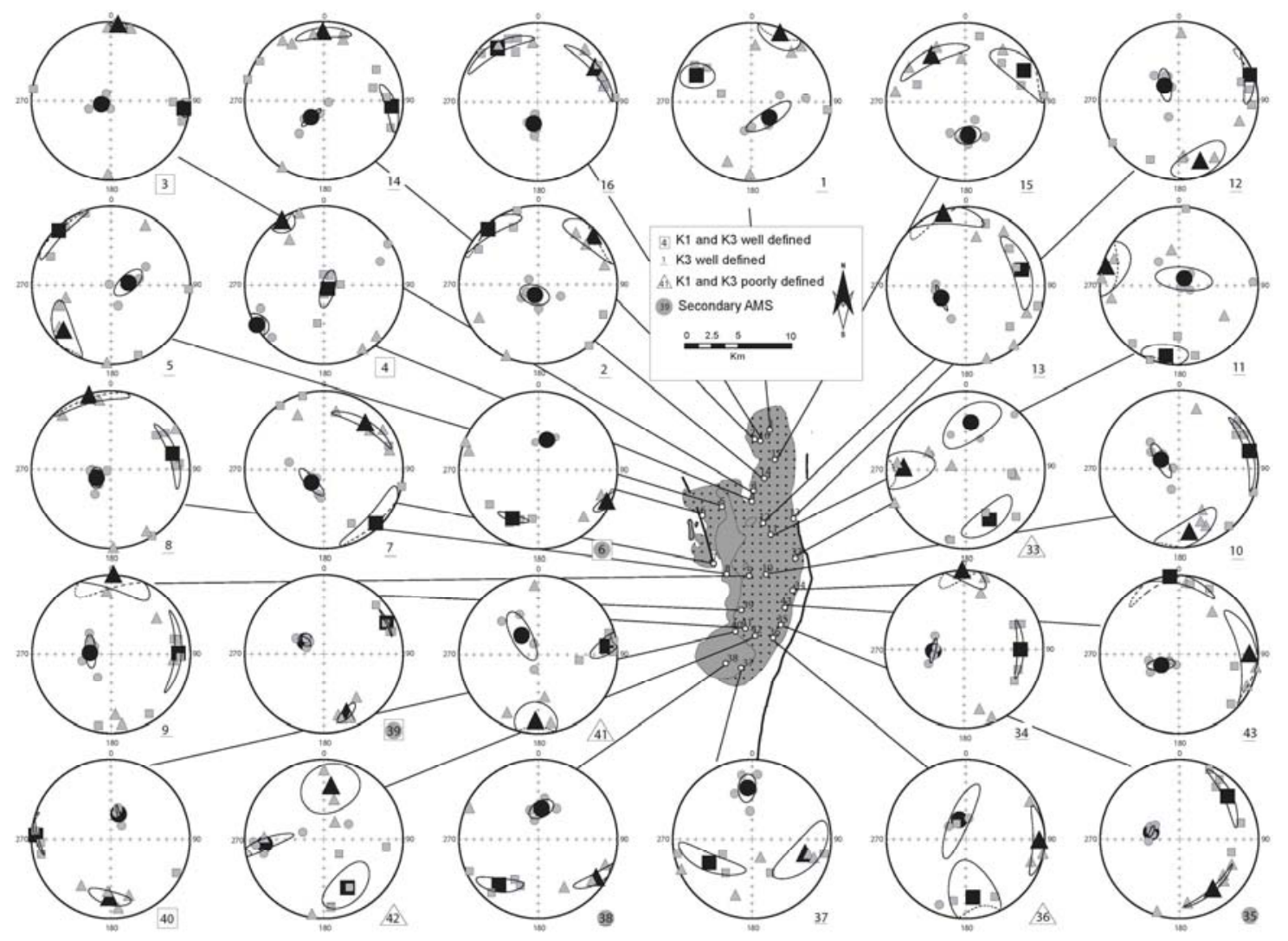




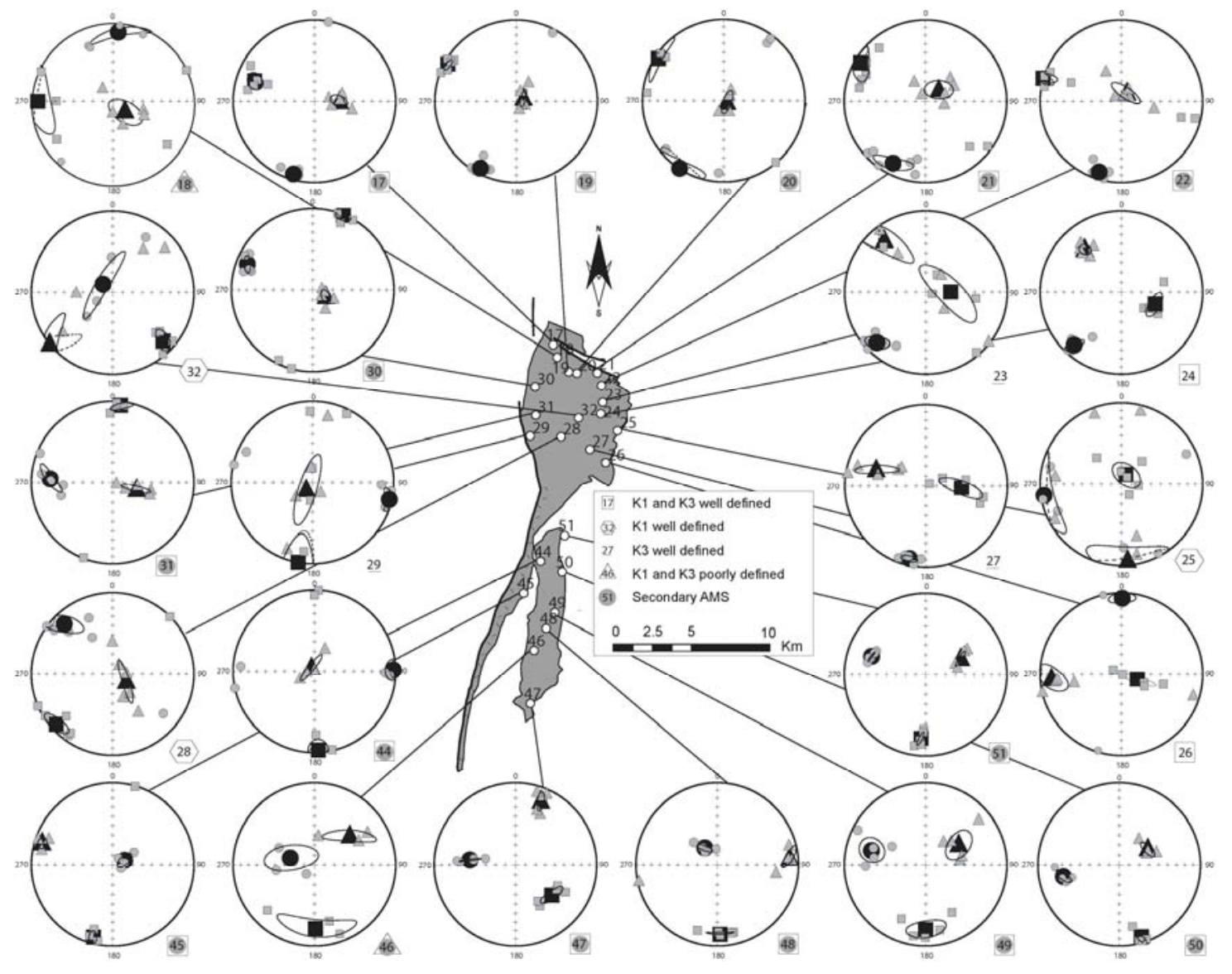




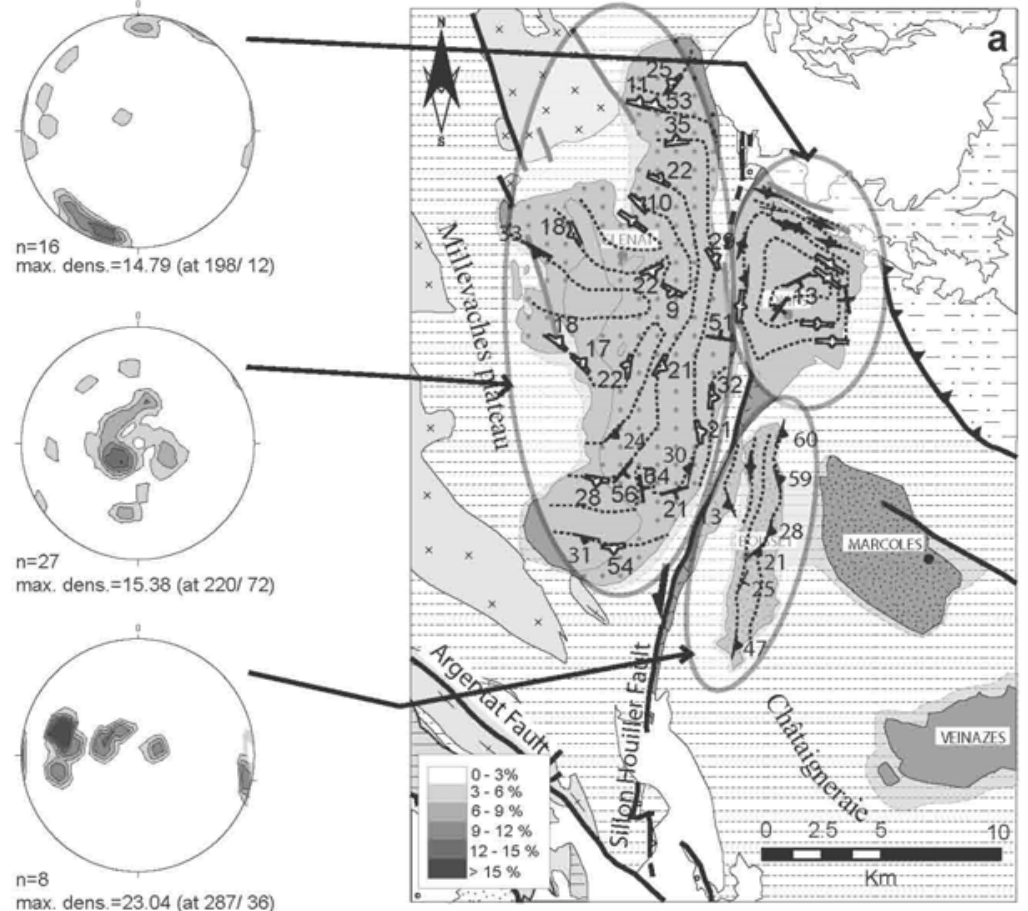

$\max$. dens. $=23.04($ at $287 / 36)$

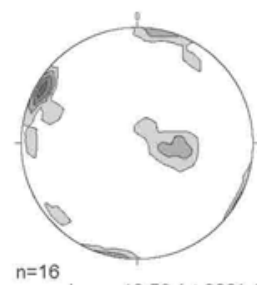

$\begin{array}{l}n=16 \\ \max \text {. dens }\end{array}=13.58$ (at $\left.300 / 6\right)$

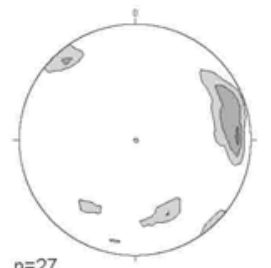

max dens $=9.50$ (at $88 / 12$ )

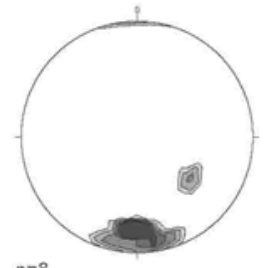

max. dens. $=37.25$ (at 180/ 18)

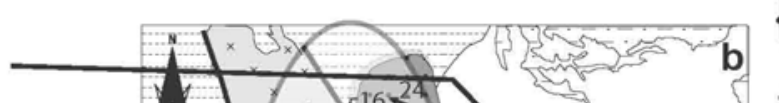

$\rightarrow 16$
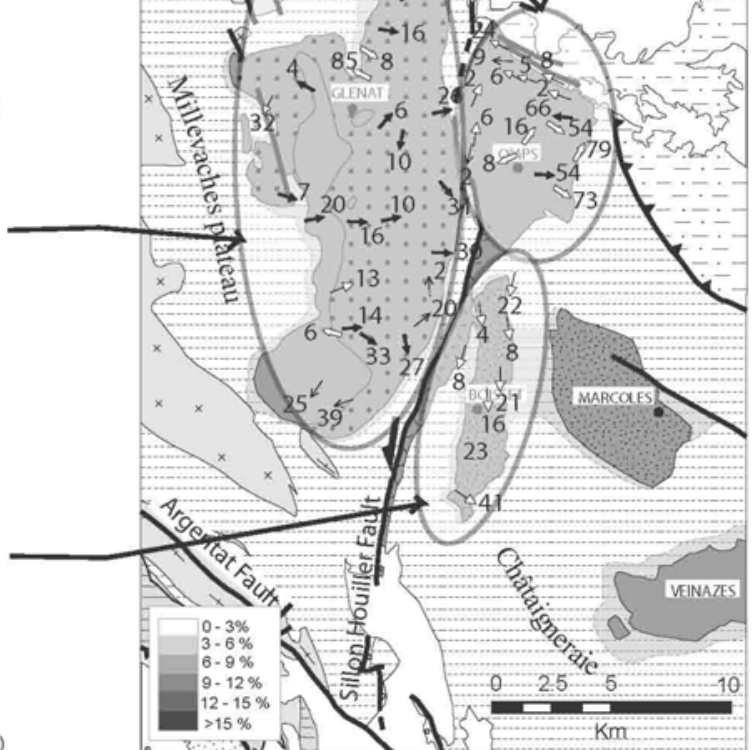

Sedimentary deposits

$\square$ Tertiary deposit

$\because$ Stephanian coal basin

Granites

a- Porphyritic granite
b-Cataclased granite

... Granodiorite

Pranodionite tended to granodiorite

Leucogranite

Metamorphic rocks

Metamorphism of contact

-... Lower Gneiss Unit

Micaschist (Para - Autochthonous

$\ldots \ldots$ Unit)

Gneiss (Limousin series)

Orthogneiss

+ allochthonous unit)

Sandstone and quartzite

(Thiviers-Peyzac Unit)

$\ldots$ Brittle strike-slip fault

_ Ductile thrust

Magmatic magnetic foliation

Bo to 69 Well-defined magnetic foliation $\checkmark>70$

$t^{0 \text { to } 69}$ Poorly-defined magnetic foliation $t^{>70}$

Post magmatic magnetic foliation po to 69 Well-defined magnetic foliation $\nmid>70$ Well-defined magnetic foliation $t^{01069}$ Poorly-defined magnetic foliation t...... Interpretative form-line of foliation

Magmatic magnetic lineation

ग10 Well-defined magnetic lineation

$\uparrow^{10}$ Poorly-defined magnetic lineation Post magmatic magnetic lineation $\hat{P}^{10}$ Well-defined magnetic lineation

$\uparrow^{10}$ Poorly-defined magnetic lineation 


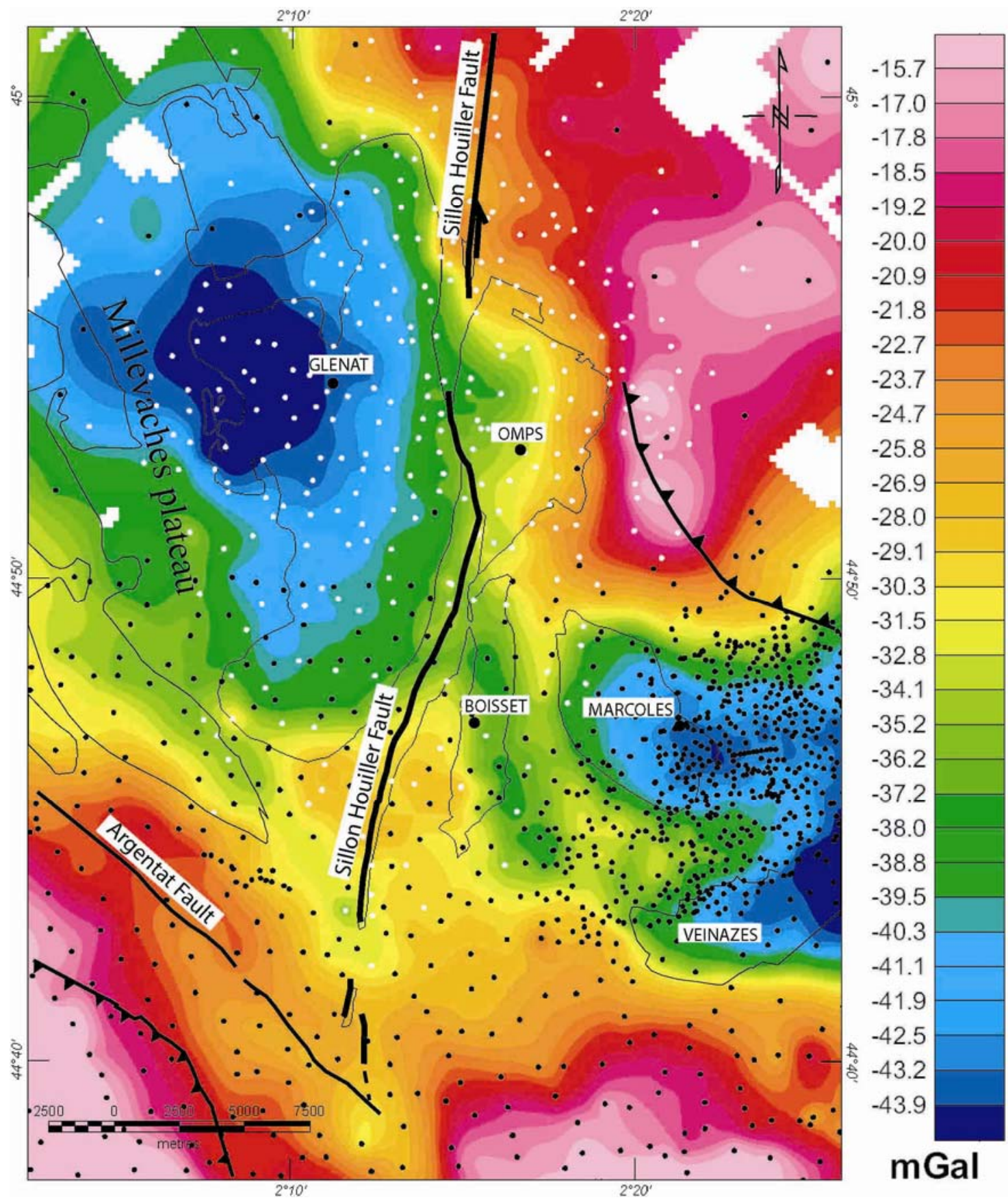



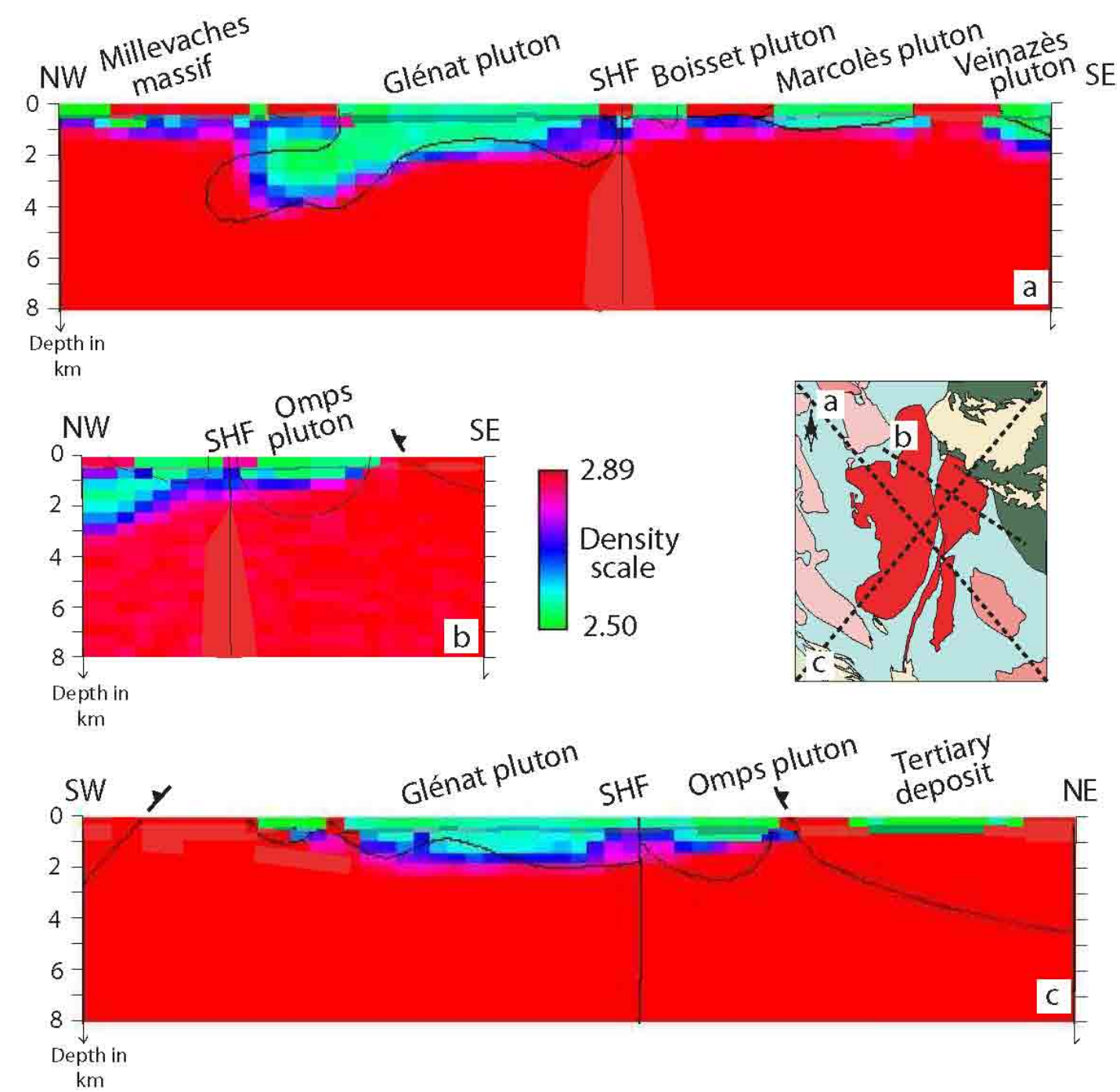


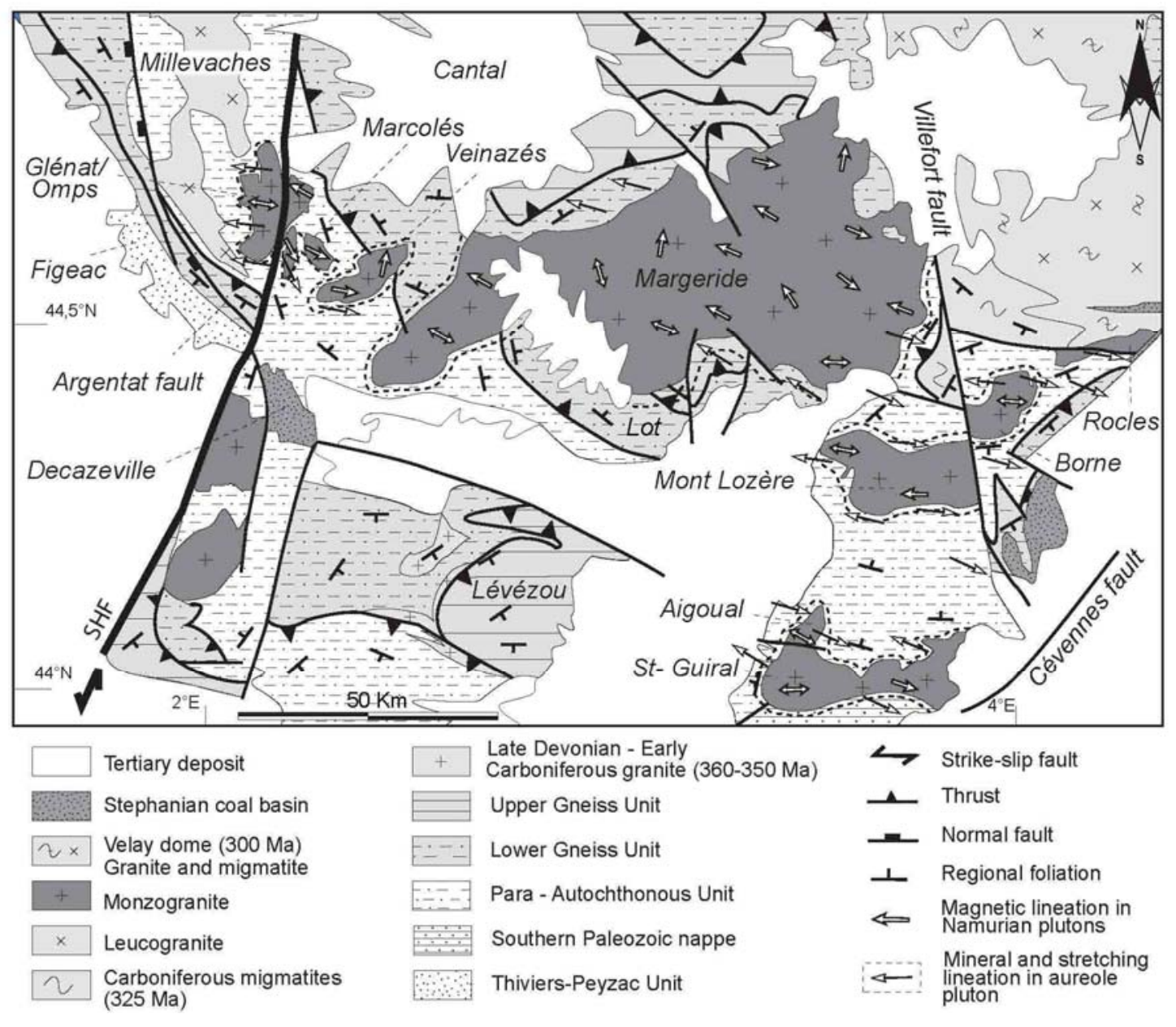




\begin{tabular}{|c|c|c|c|c|c|c|c|c|c|c|c|c|c|c|c|}
\hline \multirow{2}{*}{ Station } & \multirow{2}{*}{ Type } & \multirow{2}{*}{ Latitude $\left({ }^{\circ}\right)$} & \multirow{2}{*}{ Longitude $\left({ }^{\circ}\right)$} & \multirow{2}{*}{$n$} & \multirow{2}{*}{ BMS } & \multicolumn{4}{|c|}{ K1 } & \multicolumn{4}{|c|}{ K3 } & \multirow{2}{*}{$\mathrm{Pj}$} & \multirow{2}{*}{$\begin{array}{lll}T & \\
\end{array}$} \\
\hline & & & & & & Dec & Inc & a95min & a95max & Dec & Inc & a95min & a95max & & \\
\hline GOB1 & Glénat pluton & 44,9704 & 2,2168 & 5 & 130 & 296 & 23,9 & 11,3 & 19,7 & 131,6 & 65.5 & 8,2 & 28,6 & 1,013 & 0,234 \\
\hline GOB2 & Glénat pluton & 44,9609 & 2,1953 & 5 & 143 & 318,5 & 5,4 & 9,1 & 31,3 & 199,8 & 79 & 9,9 & 15,9 & 1,009 & 0,113 \\
\hline GOB3 & Glénat pluton & 44,9243 & 2,1933 & 5 & 126 & 96,1 & 8,4 & 5,3 & 8,9 & 249,6 & 80,3 & 5,6 & 8,6 & 1,014 & 0,146 \\
\hline GOB4 & Glénat pluton & 44,9148 & 2,1920 & 5 & 45 & 134.4 & 84,6 & 7,1 & 19,7 & 239,5 & 1,7 & 9,2 & 15,6 & 1,007 & 0,430 \\
\hline GOB5 & Glénat pluton & 44,9200 & 2,1487 & 5 & 67 & 316,5 & 4,3 & 8,1 & 28 & 82,1 & 72 & 8,4 & 19 & 1.015 & 0,070 \\
\hline GOB6 & Glénat pluton & 44,9017 & 2,1406 & 5 & 59 & 207,8 & 32,2 & 3,9 & 15 & 16,4 & 56,9 & 1 & 7,7 & 1,023 & 0,136 \\
\hline GOB7 & Glénat pluton & 44,8662 & 2,1504 & 5 & 89 & 135,5 & 6,9 & 13 & 36,6 & 224,5 & 71,6 & 5,4 & 18,3 & 1,012 & 0,819 \\
\hline GOB8 & Glénat pluton & 44,8578 & 2,1659 & 5 & 89 & 76,6 & 20,2 & 5,1 & 32,8 & 240 & 73,2 & 6,7 & 10,7 & 1,014 & 0,694 \\
\hline GOB9 & Glénat pluton & 44,8568 & 2,1891 & 5 & 93 & 89 & 16,4 & 4,3 & 40,8 & 276,6 & 68,2 & 5,6 & 17,1 & 1,013 & 0,502 \\
\hline GOB10 & Glénat pluton & 44,8578 & 2,2091 & 5 & 71 & 75,8 & 10 & 4,8 & 34,9 & 295,3 & 69,5 & 5,7 & 19,9 & 1,025 & 0,422 \\
\hline GOB11 & Glénat pluton & 44,8877 & 2,2120 & 5 & 88 & 191,3 & 10,3 & 14,3 & 20,1 & 35,9 & 81 & 12,1 & 32,6 & 1,008 & 0,002 \\
\hline GOB12 & Glénat pluton & 44,8962 & 2,2052 & 5 & 78 & 69,6 & 5,8 & 6.6 & 27,2 & 319,1 & 68,3 & 6,2 & 18 & 1,015 & 0,431 \\
\hline GOB13 & Glénat pluton & 44,9001 & 2,2367 & 5 & 66 & 74,2 & 27,5 & 10,6 & 39,6 & 243,9 & 61,8 & 2,2 & 13,9 & 1,016 & 0,858 \\
\hline GOB14 & Glénat pluton & 44,9294 & 2,2062 & 6 & 129 & 95,2 & 15,5 & 6,1 & 24,5 & 216,3 & 68 & 2,8 & 13,7 & 1,013 & 0,502 \\
\hline GOB15 & Glénat pluton & 44,9453 & 2,2169 & 5 & 147 & 61,5 & 17,2 & 15,2 & 39,4 & 175,3 & 55,3 & 9,2 & 12,9 & 1,007 & 1,000 \\
\hline GOB16 & Glénat pluton & 44,9593 & 2,2023 & 6 & 154 & 323,5 & 15,7 & 6,5 & 36 & 192,2 & 37,3 & 3,1 & 7,2 & 1,011 & 0,801 \\
\hline GOB33 & Glénat pluton & 44,8728 & 2,2415 & 5 & 135 & 154,3 & 31,3 & 13,1 & 31,6 & 5,7 & 39,2 & 17,6 & 40 & 1.007 & $-0,427$ \\
\hline GOB34 & Glénat pluton & 44,8462 & 2,2361 & 4 & 124 & 90,3 & 29,5 & 3.7 & 28,2 & 267,4 & 57,8 & 2,6 & 12,4 & 1,014 & 0,500 \\
\hline GOB35 & Glénat pluton & 44,8189 & 2.2229 & 5 & 134 & 48,2 & 19,5 & 5,1 & 31,2 & 285,7 & 59,9 & 2 & 6.5 & 1,011 & 0,602 \\
\hline GOB36 & Glénat pluton & 44,9731 & 2,2144 & 3 & 141 & 172,6 & 27,1 & 22 & 51,9 & 342,4 & 69 & 9,8 & 52,3 & 1,012 & 0,011 \\
\hline GOB37 & Glénat pluton & 44,7859 & 2,1804 & 5 & 156 & 241.4 & 38,5 & 9,1 & 44,2 & 354,6 & 35,9 & 8 & 16,6 & 1,006 & 0,667 \\
\hline GOB38 & Glénat pluton & 44,7875 & 2,1635 & 4 & 215 & 220,2 & 25 & 7,3 & 25,5 & 5,8 & 58,6 & 8 & 13,8 & 1,006 & 0,212 \\
\hline GOB39 & Glénat pluton & 44,8299 & 2,1775 & 4 & 97 & 63,9 & 12,5 & 1,4 & 12,2 & 302,5 & 66,5 & 3,7 & 7,1 & 1,017 & 0,403 \\
\hline GOB40 & Glénat pluton & 44,8138 & 2,1743 & $4]$ & 109 & 274,1 & 5,7 & 1,8 & 20 & 17,1 & 62,5 & 1,3 & 8,8 & 1.013 & 0,171 \\
\hline GOB41 & Glénat pluton & 44,8177 & 2,1803 & $4]$ & 117 & 83,2 & 14,2 & 6,7 & 23,1 & 318,2 & 34,2 & 10,1 & 30,7 & 1,015 & 0,460 \\
\hline GOB42 & Glénat pluton & 44,8105 & 2,1939 & 5 & 120 & 153,5 & 32,7 & 17,7 & 30,3 & 265,6 & 26 & 4,8 & 38,2 & 1,009 & 0,335 \\
\hline GOB43 & Glénat pluton & 44,8333 & 2,2271 & 4 & 117 & 353 & 1,6 & 6,3 & 51,9 & 240,5 & 68.7 & 5,7 & 15.2 & 1.010 & 0,546 \\
\hline GOB44 & Glénat pluton & 44,8154 & 2,2578 & 4 & 108 & 177,2 & 3,8 & 7,5 & 13,8 & 89 & 3,1 & 7,9 & 11 & 1,057 & 1,000 \\
\hline GOB17 & Omps pluton & 44,9270 & 2,2661 & 5 & 121 & 288,8 & 23,5 & 6,4 & 10,2 & 195,8 & 7 & 5,2 & 7,2 & 1,056 & 0,161 \\
\hline GOB18 & Omps pluton & 44,9219 & 2,2680 & 5 & 112 & 269,7 & 9,3 & 14.9 & 31 & 5,1 & 15,7 & 4.5 & 29,1 & 1.039 & 0,220 \\
\hline GOB19 & Omps pluton & 44,9139 & 2,2775 & 6 & 106 & 298,3 & 5,7 & 3 & 4,8 & 208,1 & 6,9 & 4,3 & 9 & 1,050 & 0,073 \\
\hline GOB2O & Omps pluton & 44,9133 & 2,2862 & 4 & 76 & 303,2 & 5 & 4,8 & 19,7 & 213,1 & 0,3 & 10,6 & 19,8 & 1,031 & 0,227 \\
\hline GOB21 & Omps pluton & 44,9131 & 2,2964 & 6 & 101 & 300,7 & 8,1 & 8,9 & 18,8 & 207,2 & 14,4 & 6,8 & 18 & 1,023 & 0,278 \\
\hline GOB22 & Omps pluton & 44,8500 & 2,2964 & 6 & 105 & 286,7 & 1,5 & 3,7 & 17,4 & 197.7 & 9,1 & 4,2 & 7,2 & 1,041 & 0,637 \\
\hline GOB23 & Omps pluton & 44,9040 & 2,2997 & 5 & 83 & 90 & 65,6 & 12,6 & 47,1 & 223,9 & 15 & 6,3 & 13 & 1,025 & 0,742 \\
\hline GOB24 & Omps pluton & 44.8942 & 2,3011 & 5 & 106 & 110.9 & 53.9 & 5.9 & 12,9 & 221,3 & 13.9 & 3.4 & 12.6 & 1.049 & 0.401 \\
\hline GOB25 & Omps pluton & 44,8811 & 2,3100 & 6 & 113 & 28,8 & 79,4 & 10,2 & 16,6 & 261,6 & 4,6 & 12,4 & 37,3 & 1,141 & $-0,341$ \\
\hline GOB26 & Omps pluton & 44,8677 & 2,3023 & 5 & 135 & 108,7 & 72,8 & 2,9 & 19,8 & 0,5 & 6,8 & 6.6 & 10,6 & 1,034 & 0,280 \\
\hline GOB27 & Omps pluton & 44,8751 & 2,2906 & 5 & 110 & 92,8 & 53,9 & 6,5 & 26 & 193 & 8,9 & 4 & 6,4 & 1,048 & 0,680 \\
\hline GOB28 & Omps pluton & 44,8790 & 2,2735 & 7 & 133 & 228,2 & 7.8 & 7,3 & 12 & 316 & 15.5 & 7,3 & 23,3 & 1,034 & $-0,083$ \\
\hline GOB29 & Omps pluton & 44,8824 & 2,2491 & 5 & 88 & 190,1 & 1,9 & 10,9 & 44,2 & 103 & 2,6 & 4,3 & 12,5 & 1,033 & 0,796 \\
\hline GOB30 & Omps pluton & 44,9055 & 2,2516 & 5 & 102 & 22,4 & 1,8 & 5,9 & 6.2 & 291,5 & 14,5 & 3,5 & 8 & 1,065 & 0,273 \\
\hline GOB31 & Omps pluton & 44,8919 & 2,2590 & 5 & 105 & 6,6 & 5,8 & 3,4 & 10 & 273,5 & 23,9 & 4,1 & 18,2 & 1,070 & $-0,380$ \\
\hline GOB32 & Omps pluton & 44,8921 & 2,2803 & 4 & 115 & 33,3 & 15,8 & 5,1 & 14,1 & 311,8 & 76,8 & 6,6 & 47,5 & 1,054 & 0,118 \\
\hline GOB45 & Boisset pluton & 44,8000 & 2,2500 & 4 & 141 & 195,2 & 8 & 3,1 & 8,9 & 68,5 & 77,3 & 4,3 & 9,3 & 1,086 & 0,227 \\
\hline GOB46 & Boisset pluton & 44,7749 & 2,2519 & 3 & 119 & 178,7 & 22,5 & 10,5 & 39,3 & 287,3 & 65 & 12,5 & 30,4 & 1,057 & 0,003 \\
\hline GOB47 & Boisset pluton & 44,7486 & 2,2481 & 5 & 149 & 129,9 & 40,9 & 4,7 & 12,6 & 276.4 & 42,8 & 0.7 & 12,2 & 1.055 & 0,295 \\
\hline GOB48 & Boisset pluton & 44.7894 & 2,2575 & 5 & 127 & 177.6 & 16,3 & 3,8 & 11,3 & 3236 & 69 & 25 & 8,2 & 1.087 & 0,466 \\
\hline GOB49 & Boisset pluton & 44,7935 & 2,2661 & 5 & 99 & 179,3 & 21,3 & 10,1 & 17,7 & 285,5 & 31,6 & 10,5 & 15,5 & 1,035 & $-0,168$ \\
\hline GOB50 & Boisset pluton & 44.8135 & 2,2714 & 4 & 96 & 163.9 & 7.8 & 2 & 11 & 258.2 & 30,9 & 3.5 & 9.6 & 1.065 & 0,360 \\
\hline GOB51 & Boisset pluton & 44,8260 & 2,2709 & 5 & 103 & 184,5 & 22 & 1,5 & 8,7 & 288,9 & 30,3 & 0,7 & 5,1 & 1,079 & 0,513 \\
\hline
\end{tabular}

${ }^{*} \mathrm{P}_{1}=\exp \left\{2\left[\left(\ln \mathrm{K}_{1}-\ln \mathrm{Km}_{\mathrm{m}}\right)^{2}+\left(\ln \mathrm{K}_{2}-\ln \mathrm{K}_{\mathrm{m}}\right)^{2}+\left(\ln \mathrm{K}_{3}-\ln \mathrm{Km}_{\mathrm{m}}\right)^{2}\right]\right\}^{1 / 2}$ with $\mathrm{Km}_{\mathrm{m}}=\left(\mathrm{K}_{1}+\mathrm{K}_{2}+\mathrm{K}_{3}\right) / 3$ and $T=\left[2 \ln \left(K_{2} / K_{3}\right) /\left(\ln \left(K_{1} / K_{3}\right)\right]-1\right.$ 


\begin{tabular}{|l|l|l|}
\hline Formation & Rock type & $\begin{array}{l}\text { Density used for inversion } \\
\text { with its incertitude }\left(\mathrm{kg} \cdot \mathrm{m}^{-3}\right)\end{array}$ \\
\hline Tertiary deposits & Mainly calcareous sediments & $2.55(+/-0.05)$ \\
Stephanian coal basin & Sandstone & $2.55(+/-0.05)$ \\
Glénat pluton & Granite & $2.60(+/-0.03)$ \\
Omps pluton & Granite & $2.62(+/-0.03)$ \\
Boisset pluton & Granite & $2.61(+/-0.03)$ \\
Marcolès pluton & Granite & $2.60(+/-0.03)$ \\
Veinazès pluton & Granite & $2.60(+/-0.03)$ \\
Millevaches leucogranite & Leucogranite & $2.59(+/-0.03)$ \\
Lower Gneiss Unit basement & Metagraywacke, metapelite & $2.75(+/-0.05)$ \\
Parautoctonous basement & Micaschist & $2.77(+/-0.05)$ \\
Limousine serie basement & Gneiss & $2.72(+/-0.05)$ \\
High grade alloctonous unit basement & Orthogneiss & $2.77(+/-0.05)$ \\
\hline
\end{tabular}

